\title{
Preparation and Use of Enantioenriched Allenylsilanes for the Stereoselective Synthesis of Homopropargylic Ethers
}

Supporting Information 2: ${ }^{1} \mathrm{H}$ and ${ }^{13} \mathrm{C}$ NMR spectra

Ryan A. Brawn and James S. Panek*

Department of Chemistry and Center for Chemical Methodology and Library

Development, Metcalf Center for Science and Engineering, 590 Commonwealth Avenue, Boston University, Boston, Massachusetts 02215 


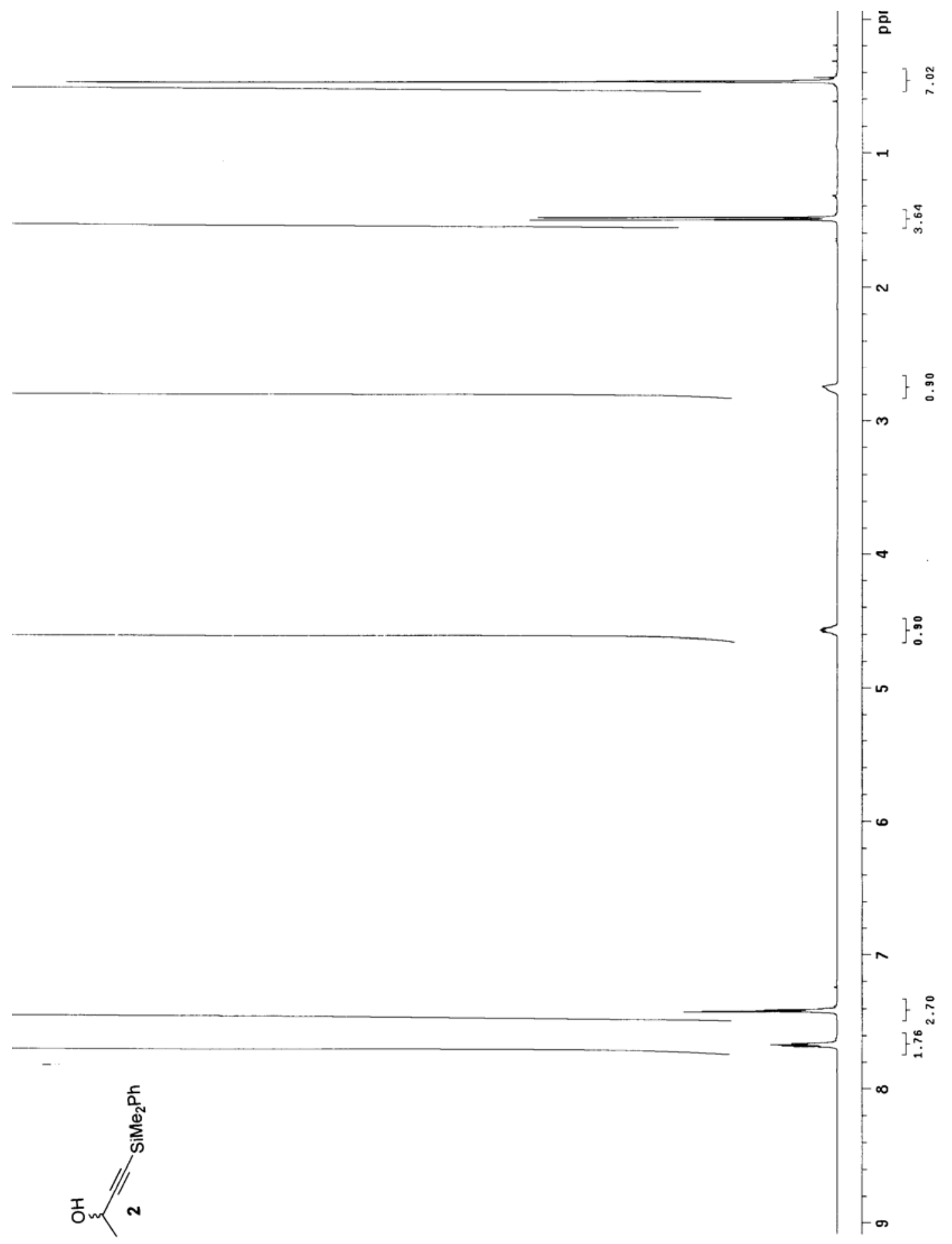

SI-19 


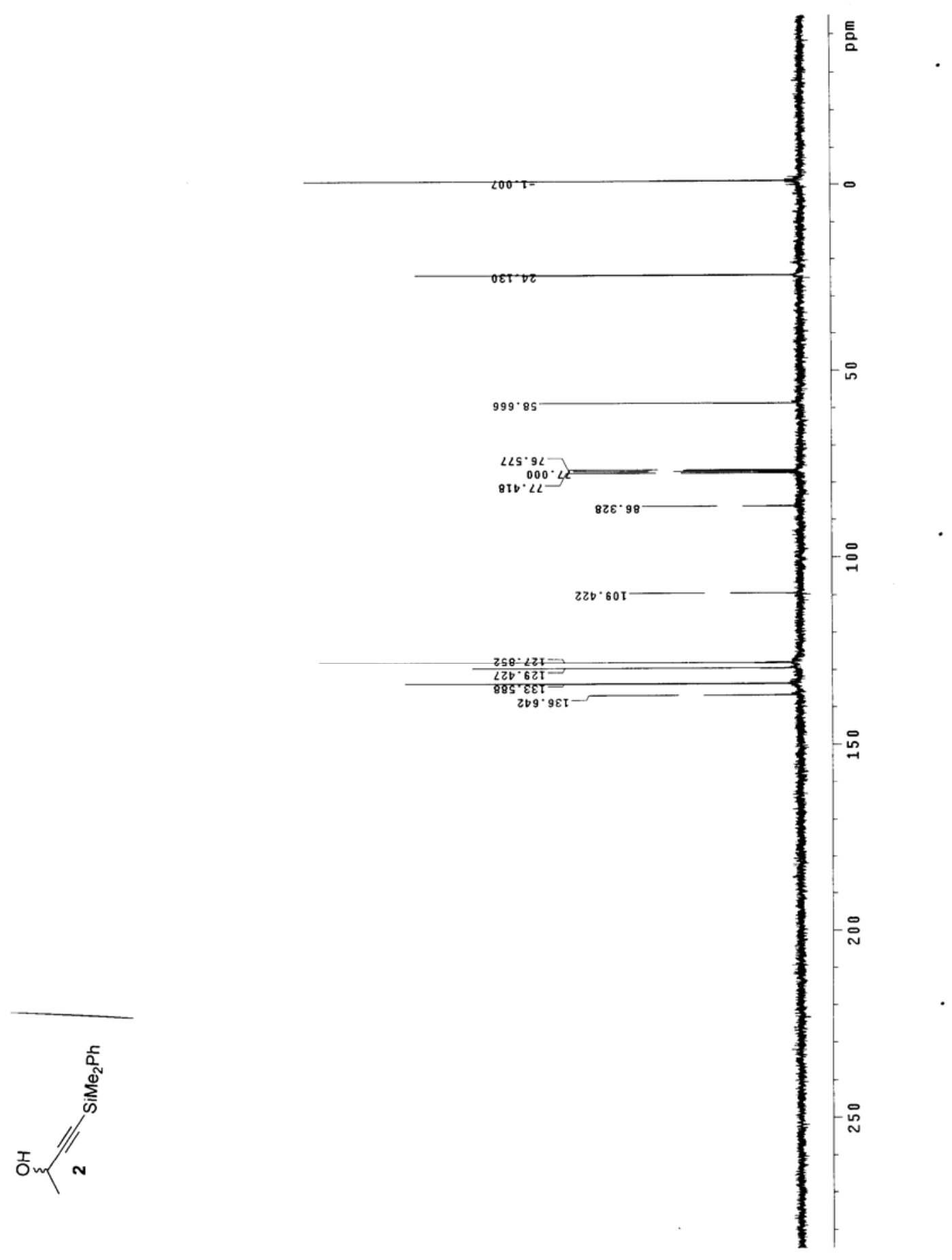




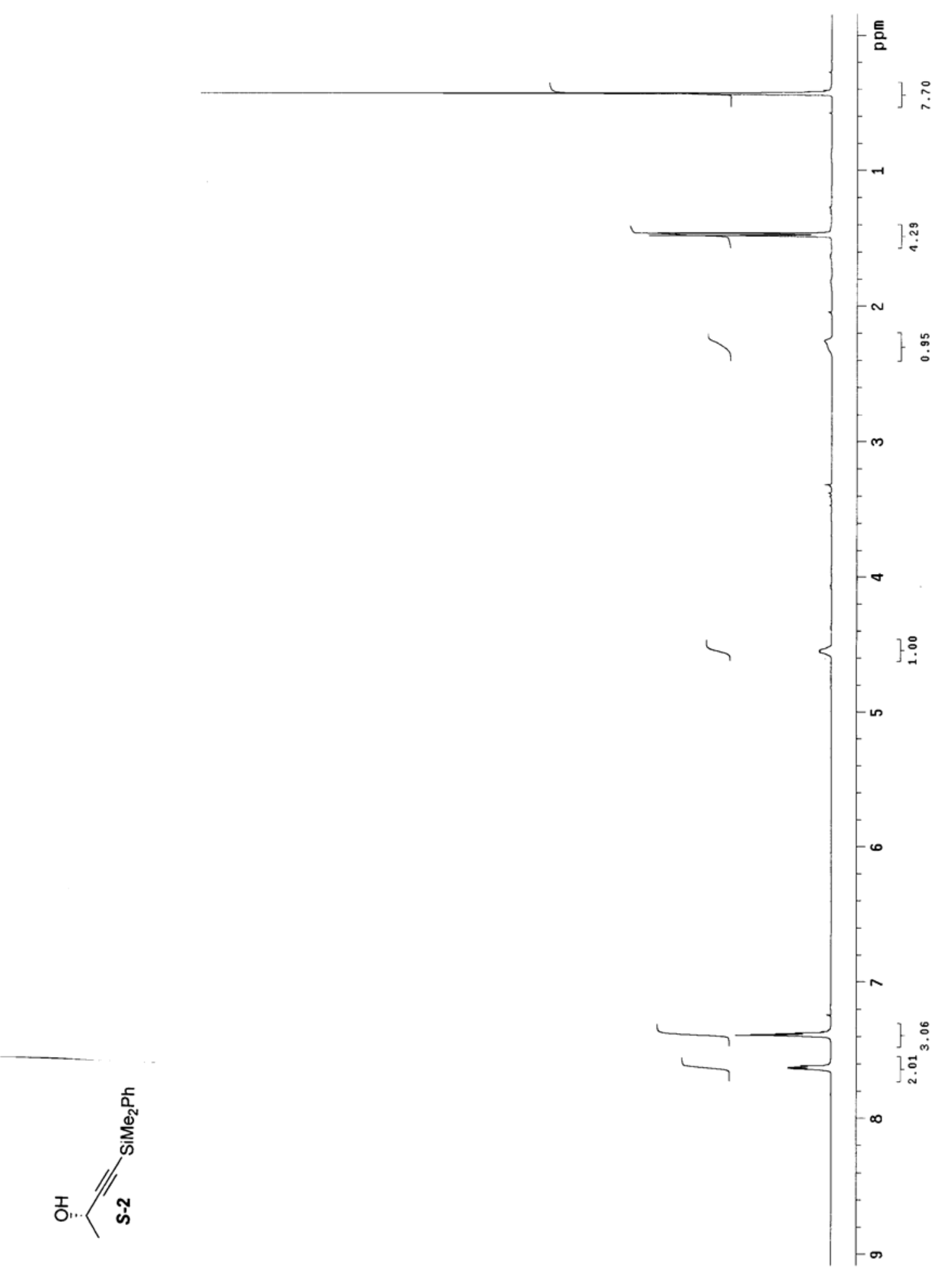

SI-21 


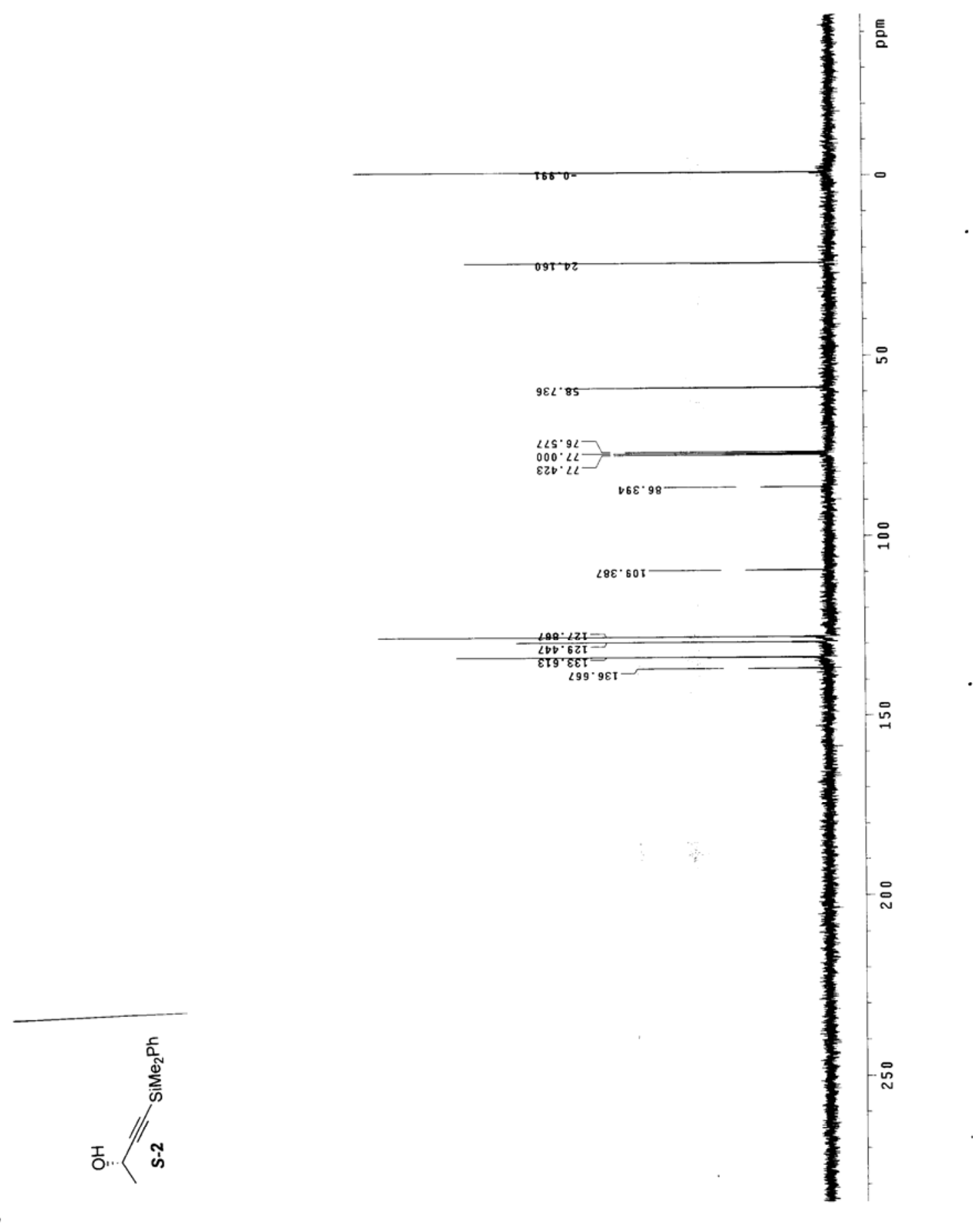




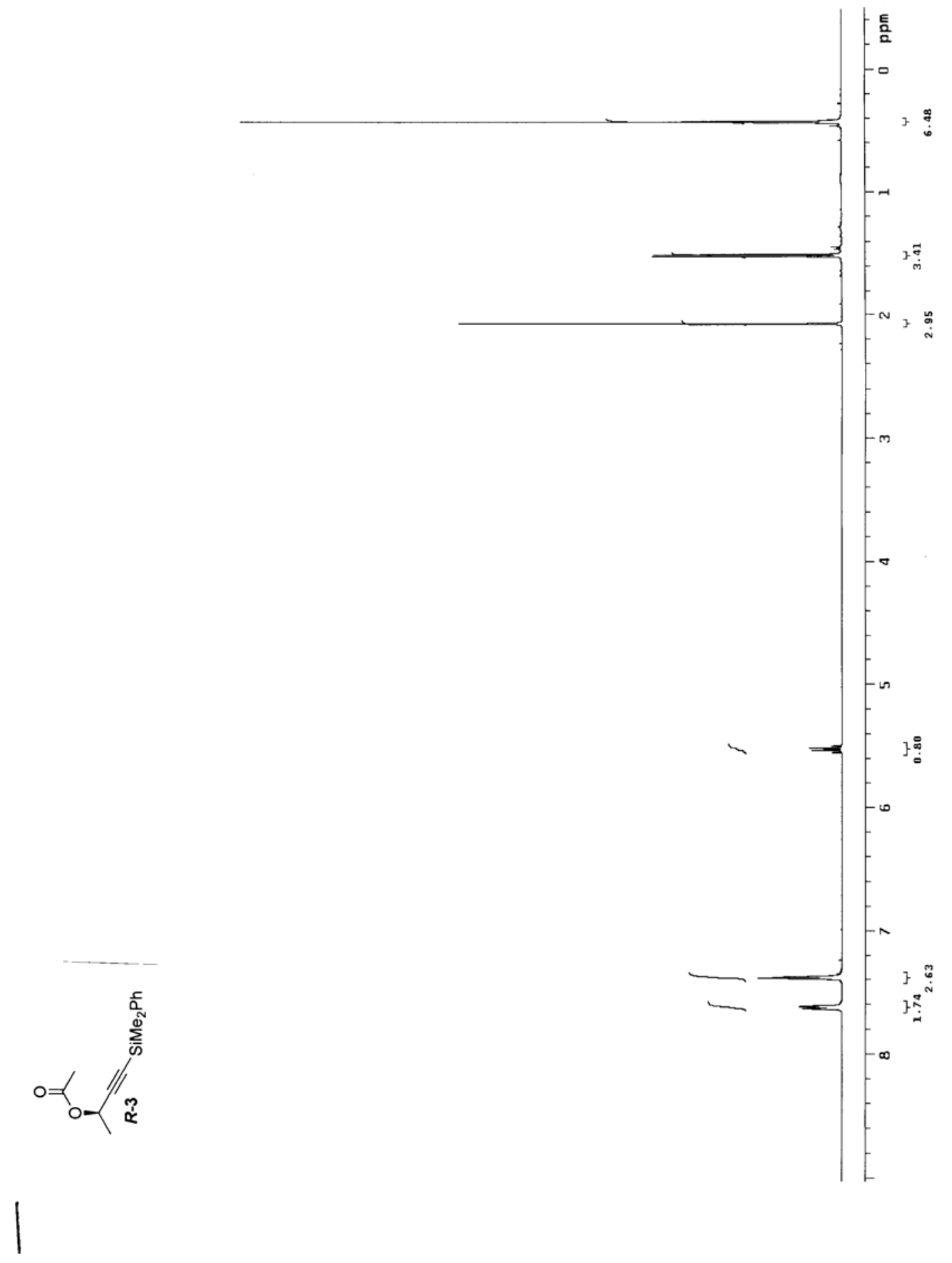

SI-23 


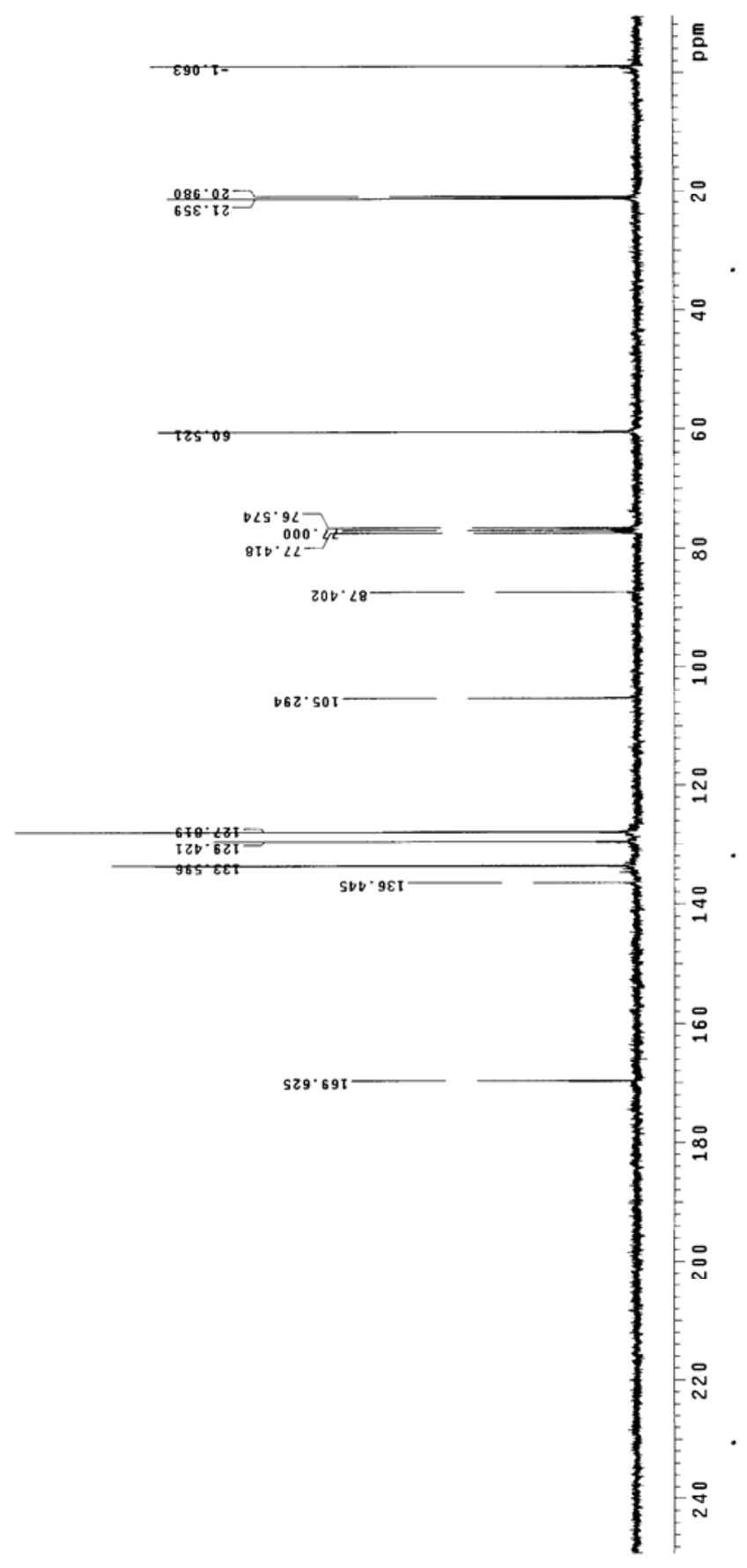

SI-24 


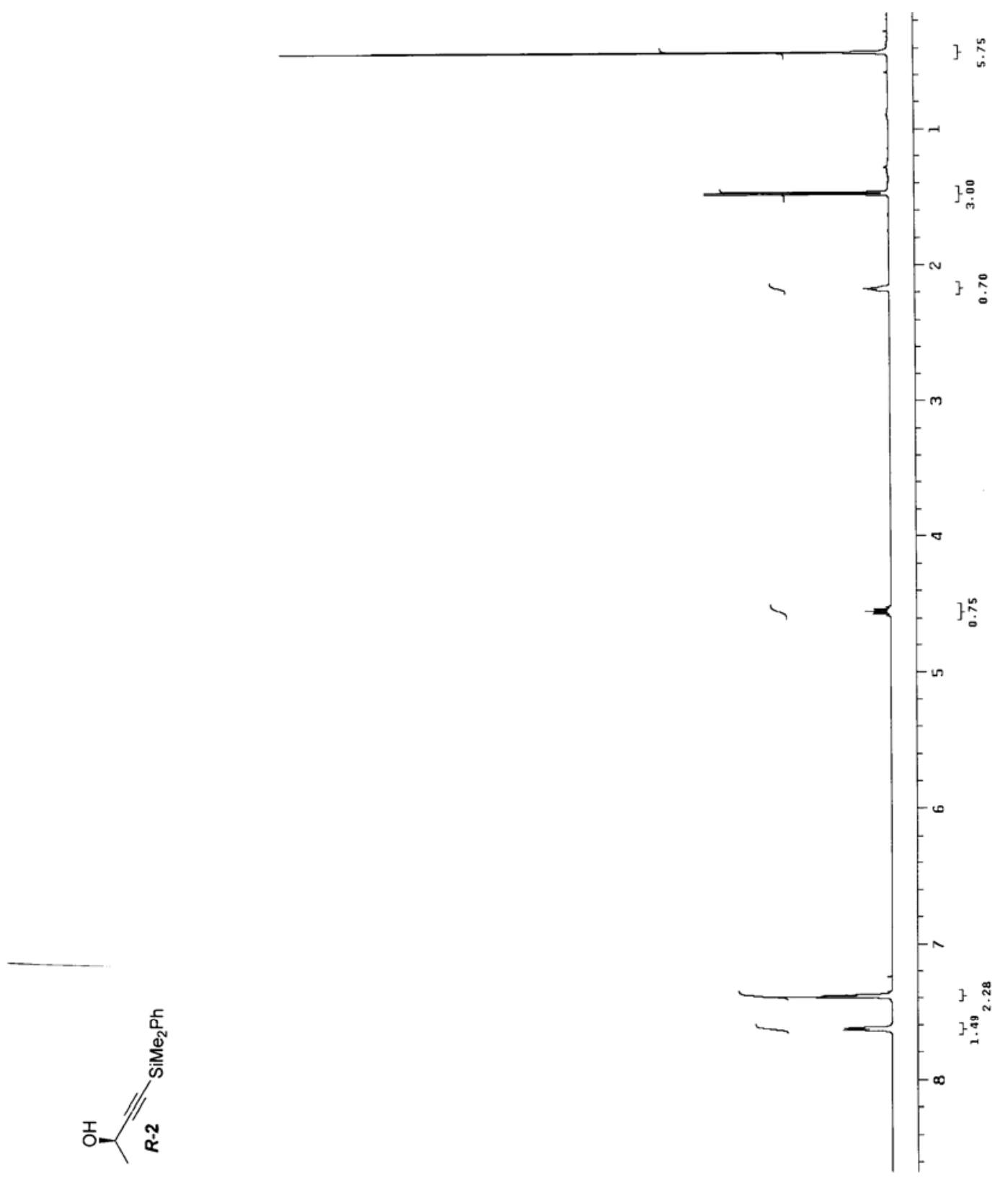

SI-25 


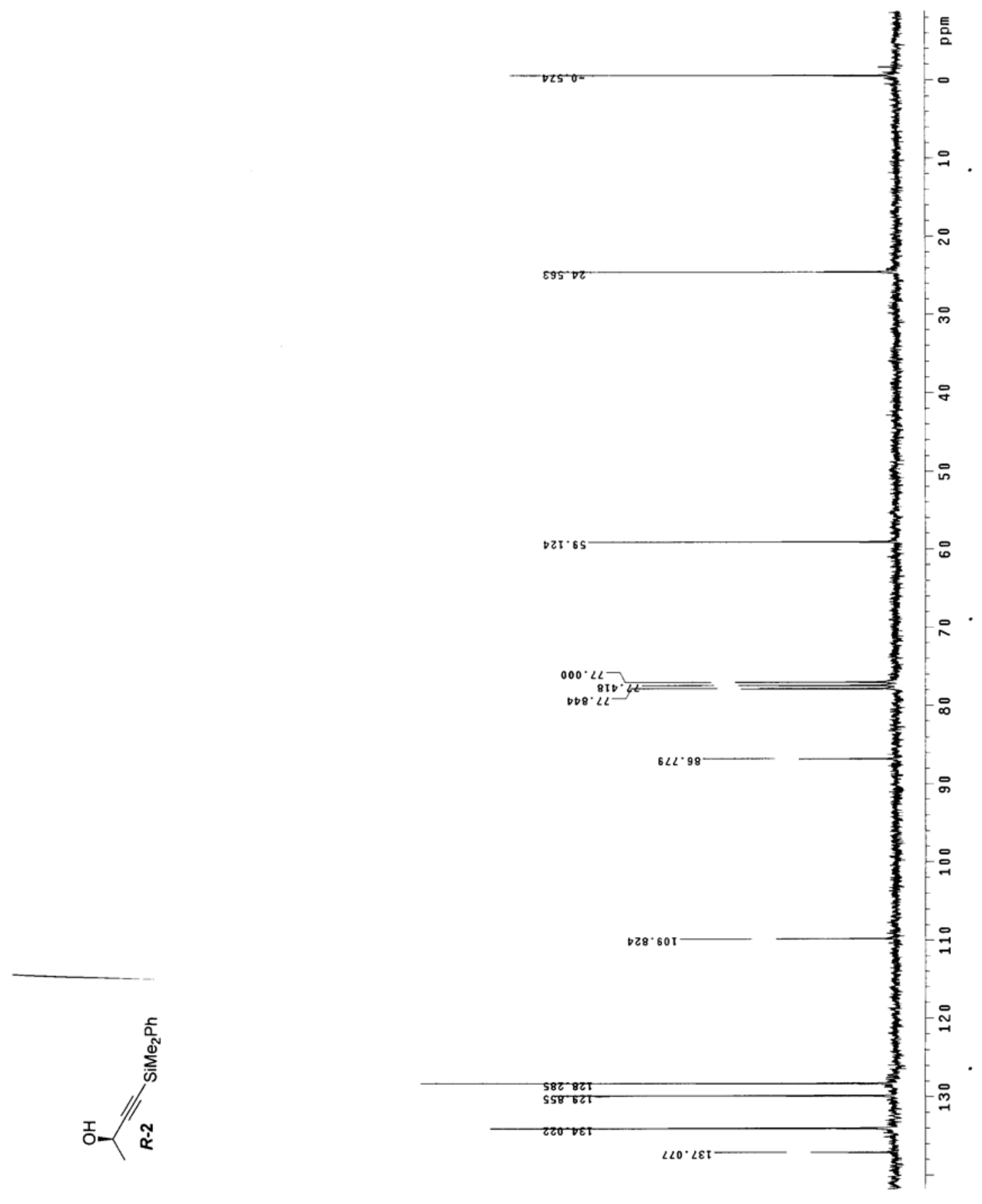




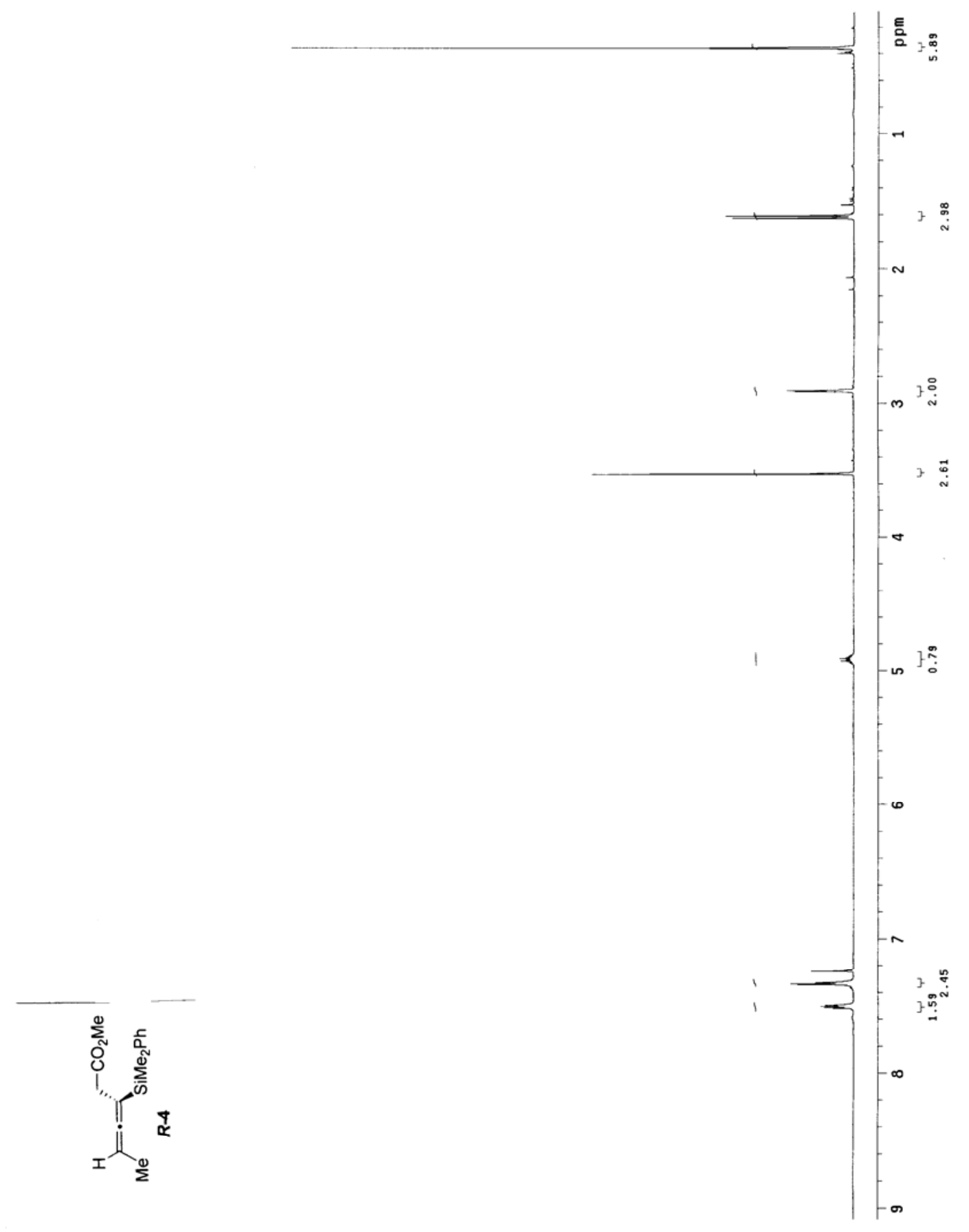

SI-27 


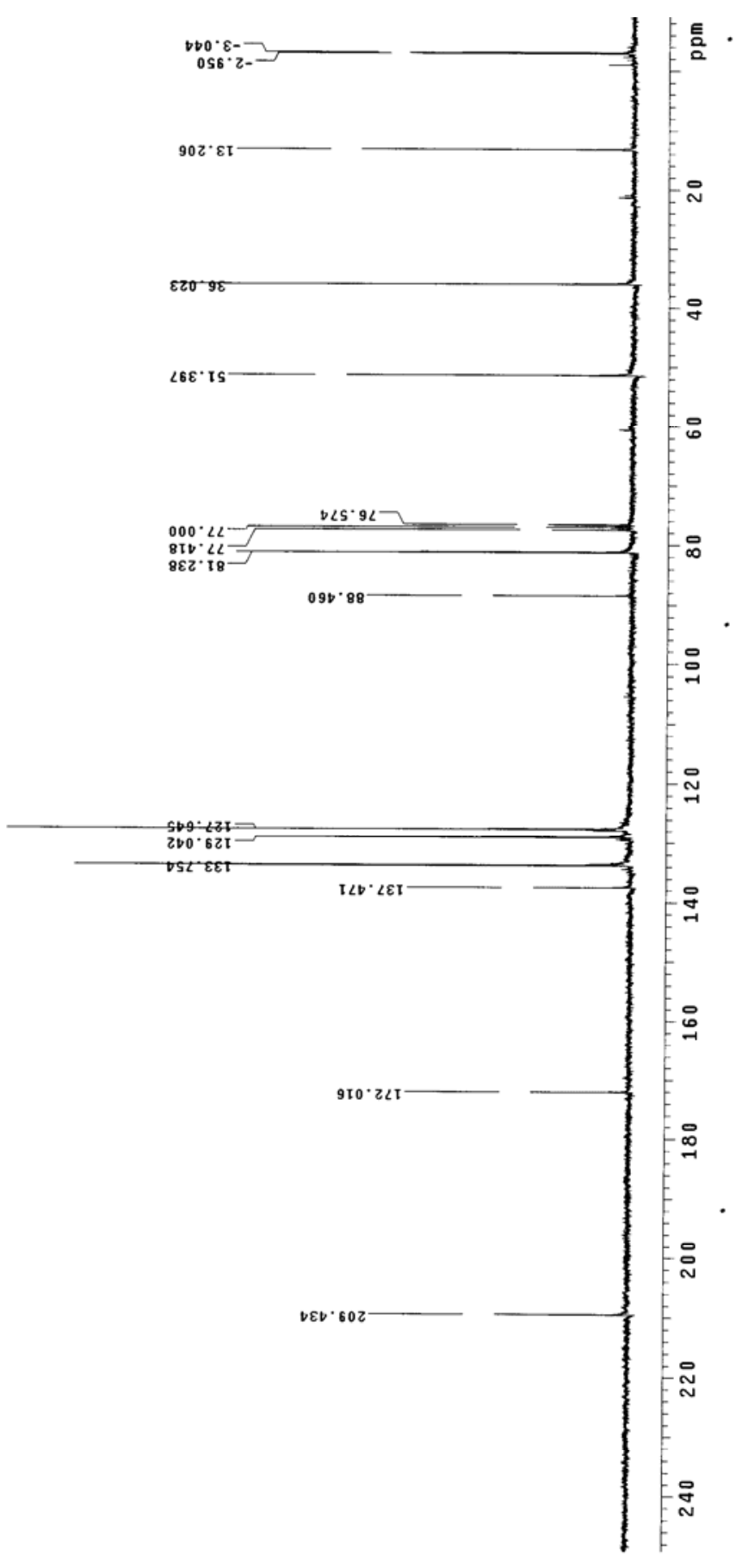




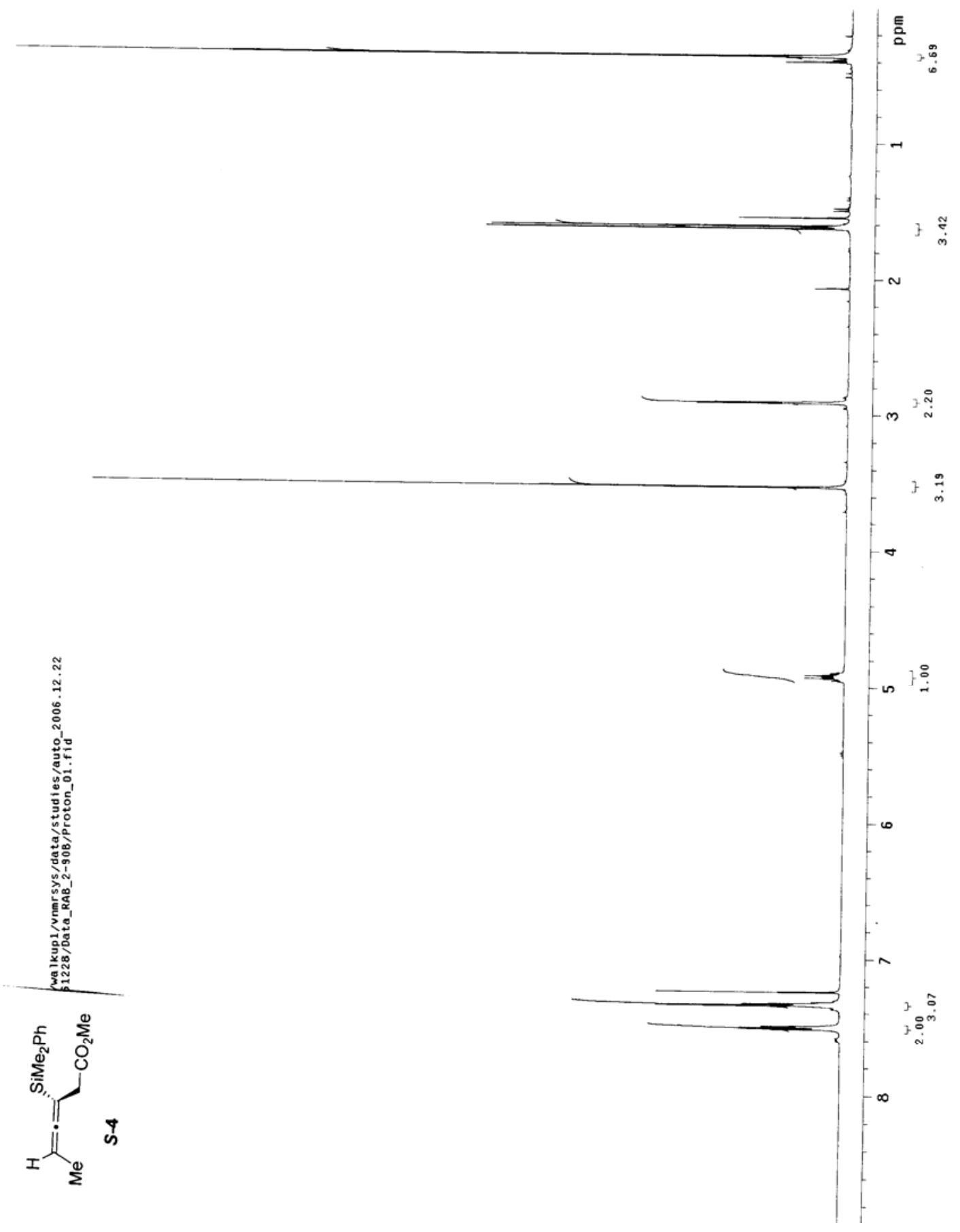

SI-29 


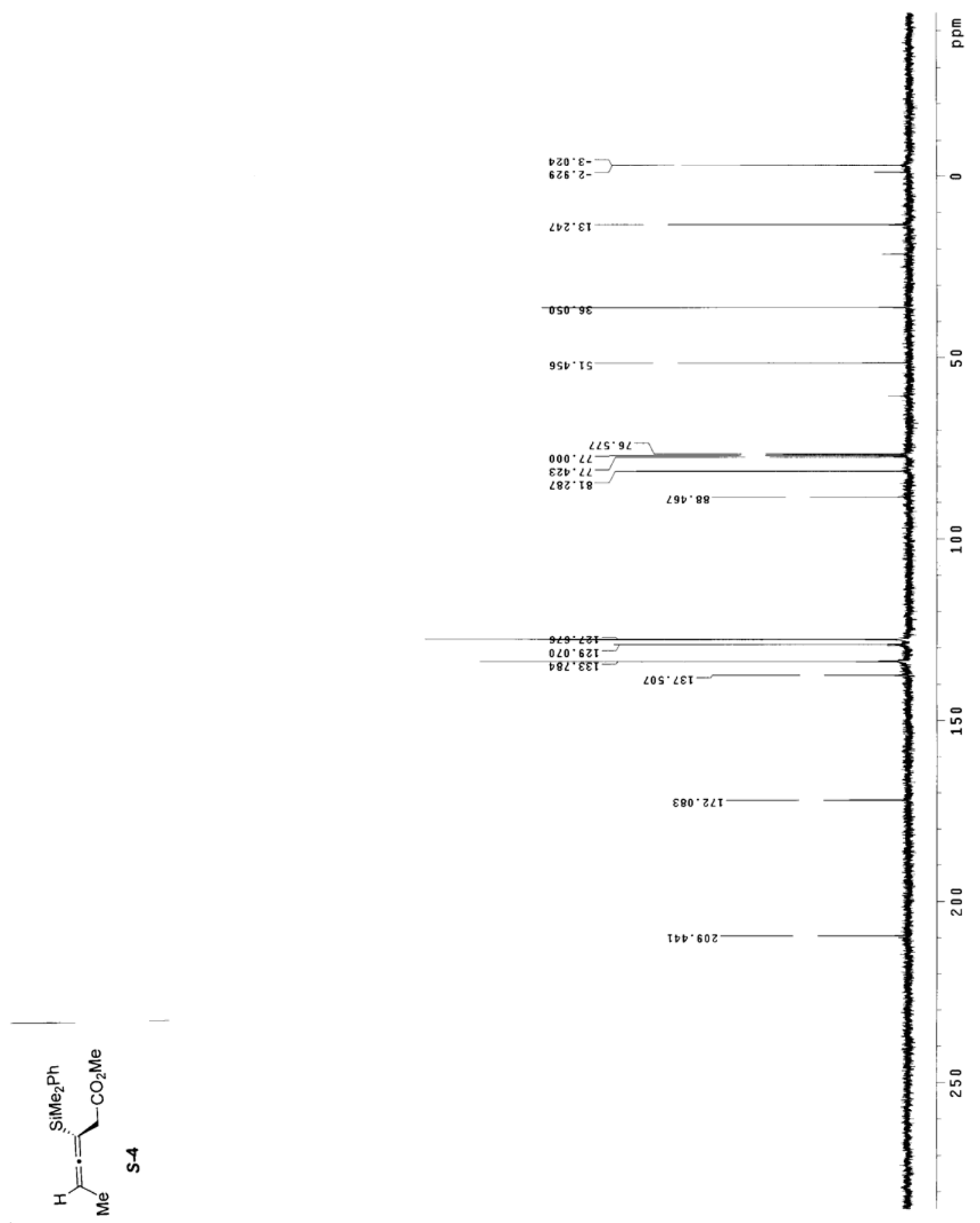

SI-30 


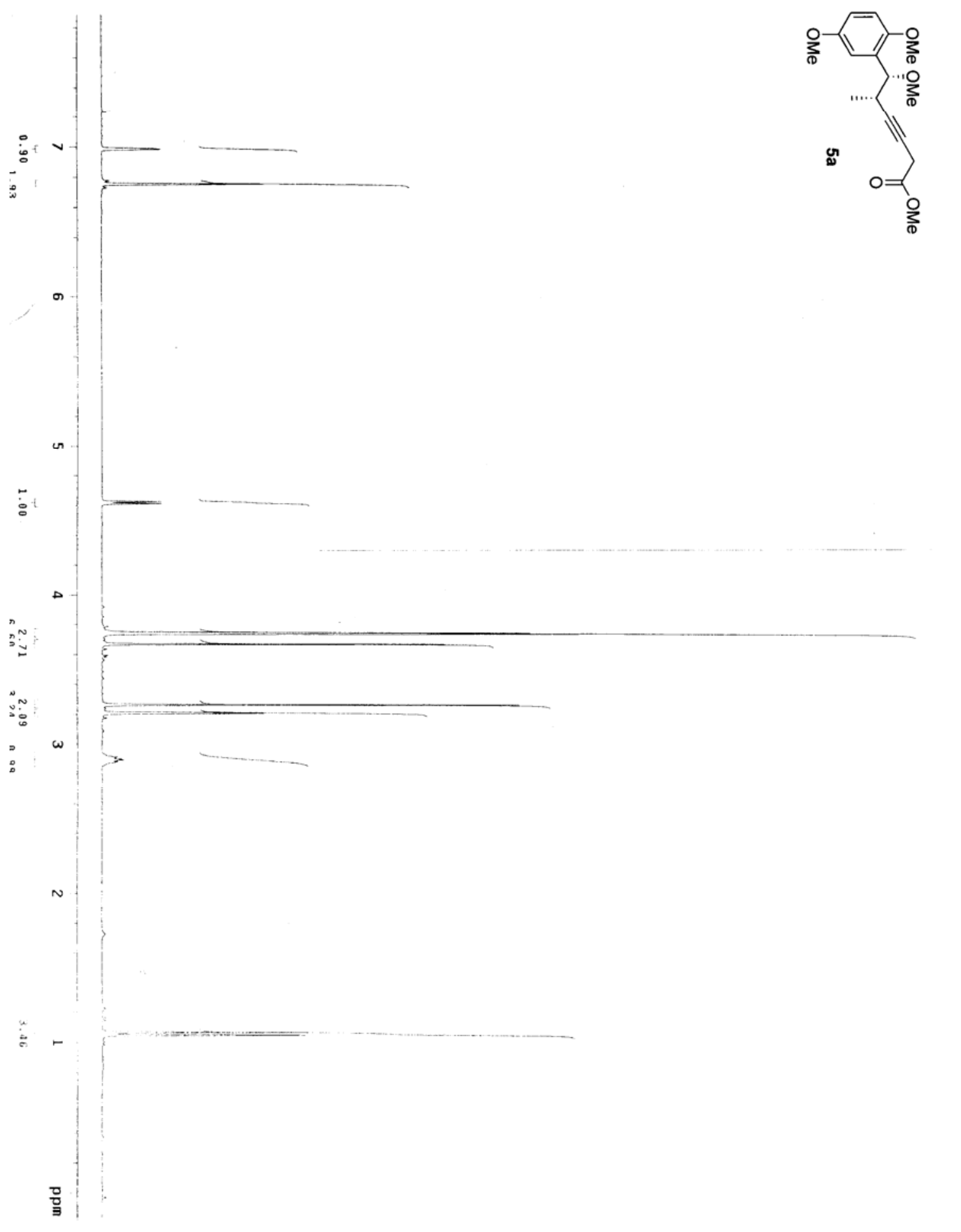

SI-31 


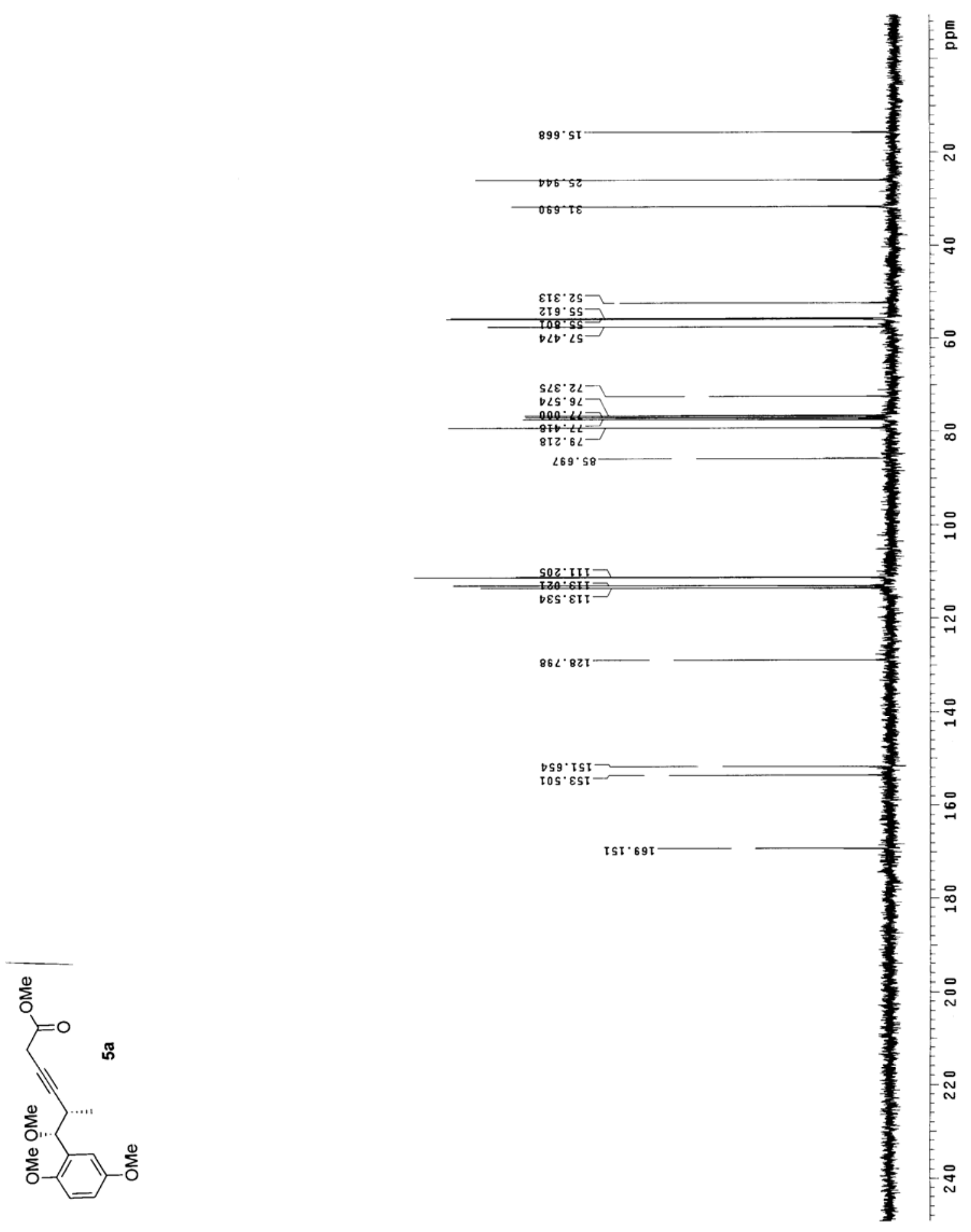




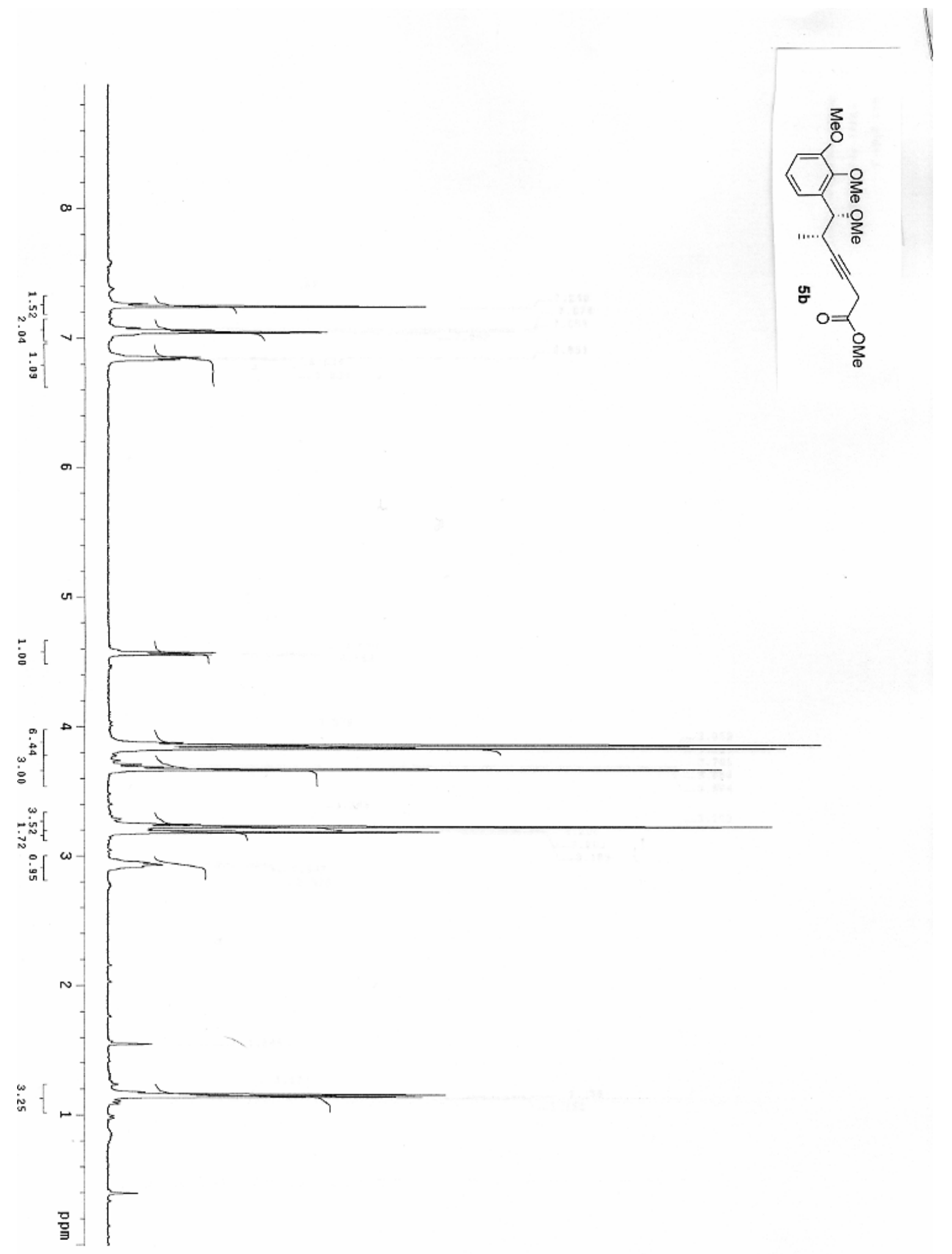




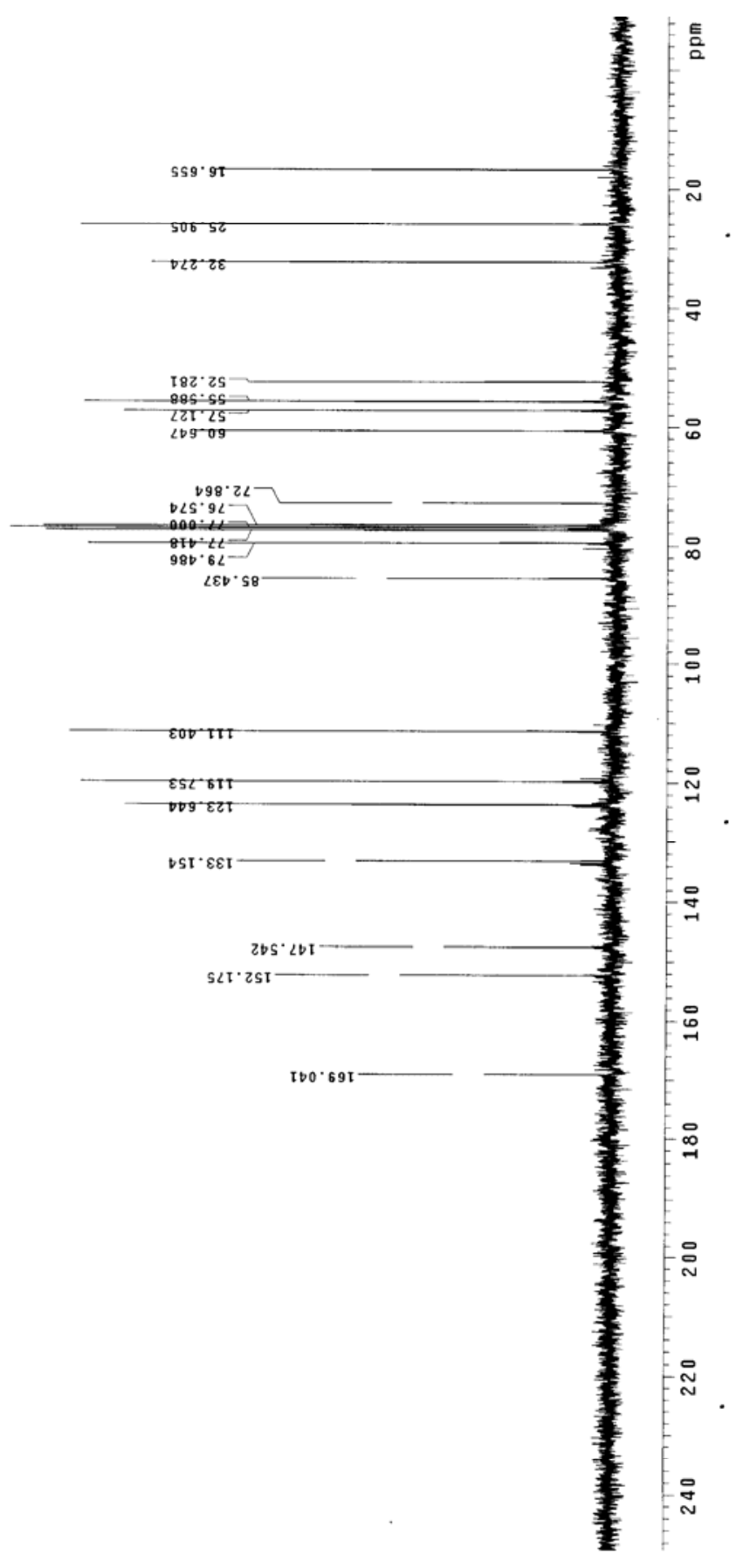




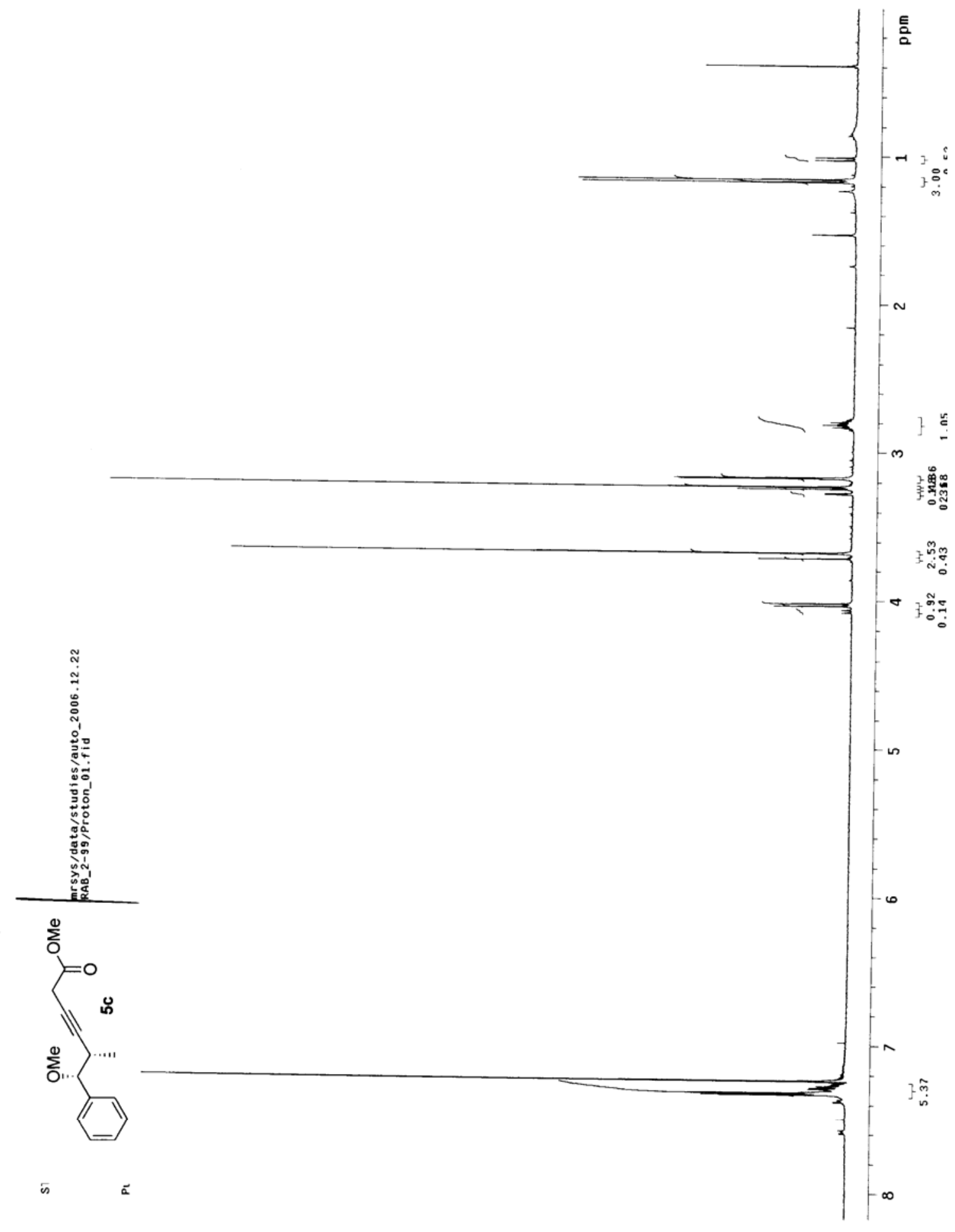




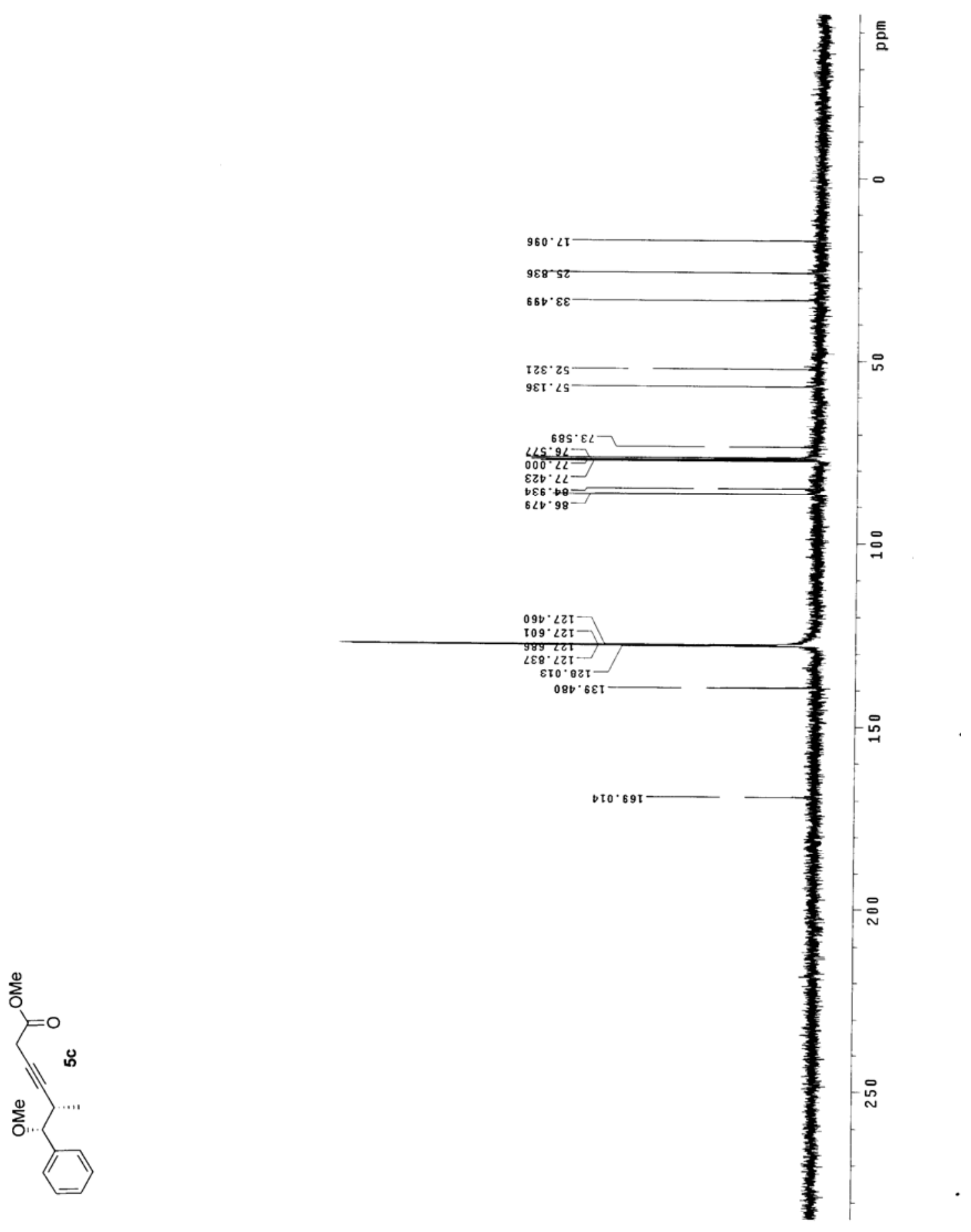




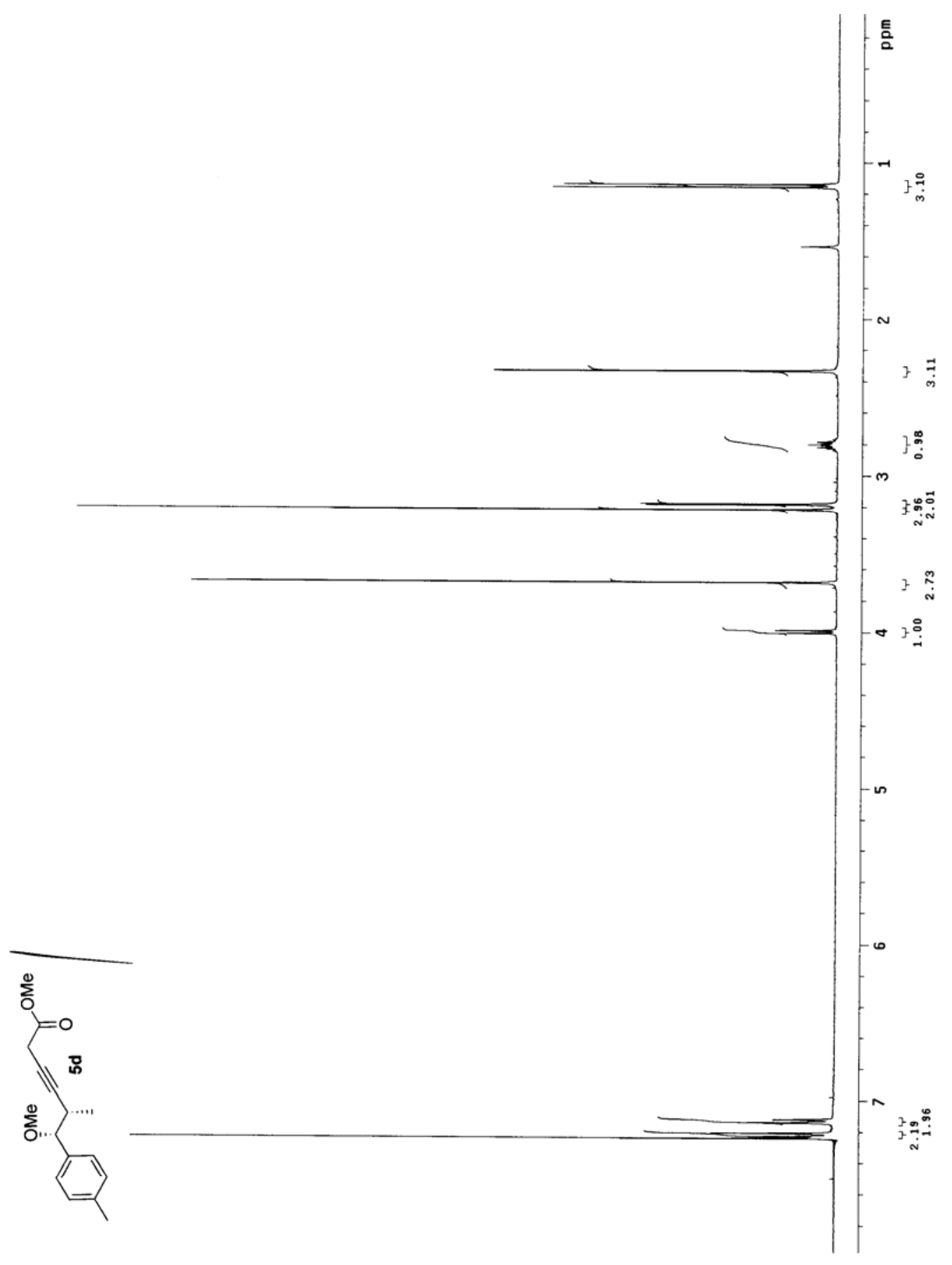

SI-37 


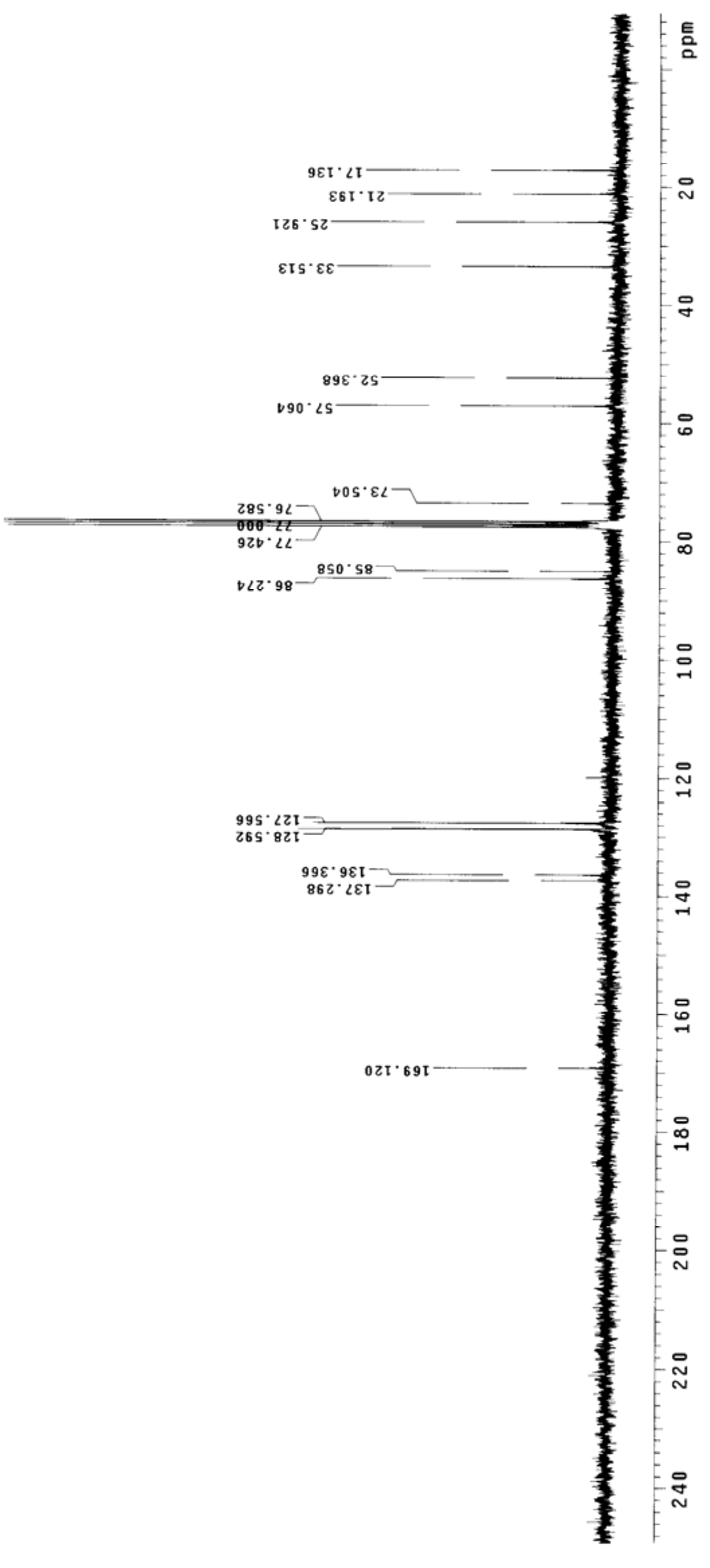




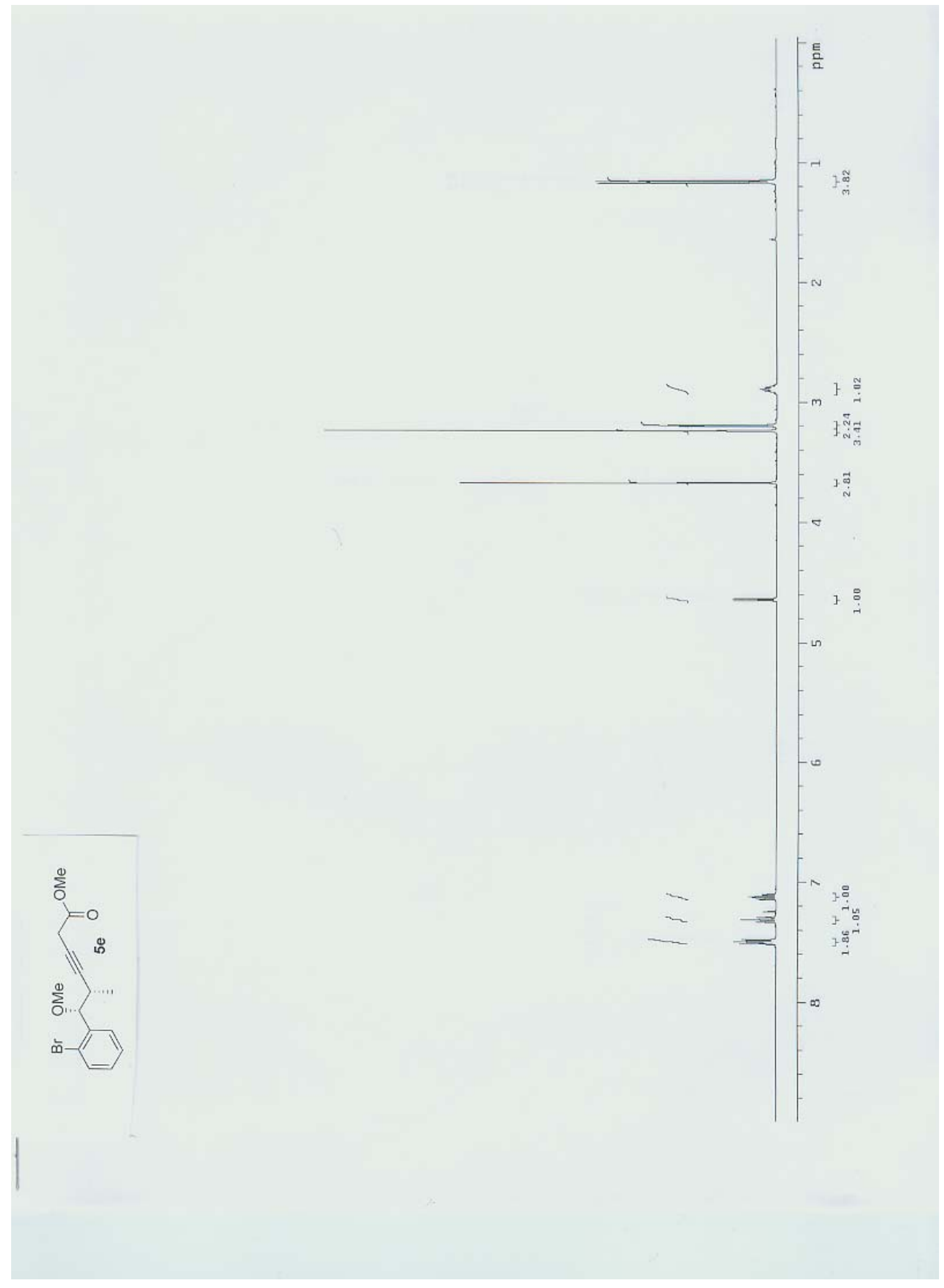

SI-39 


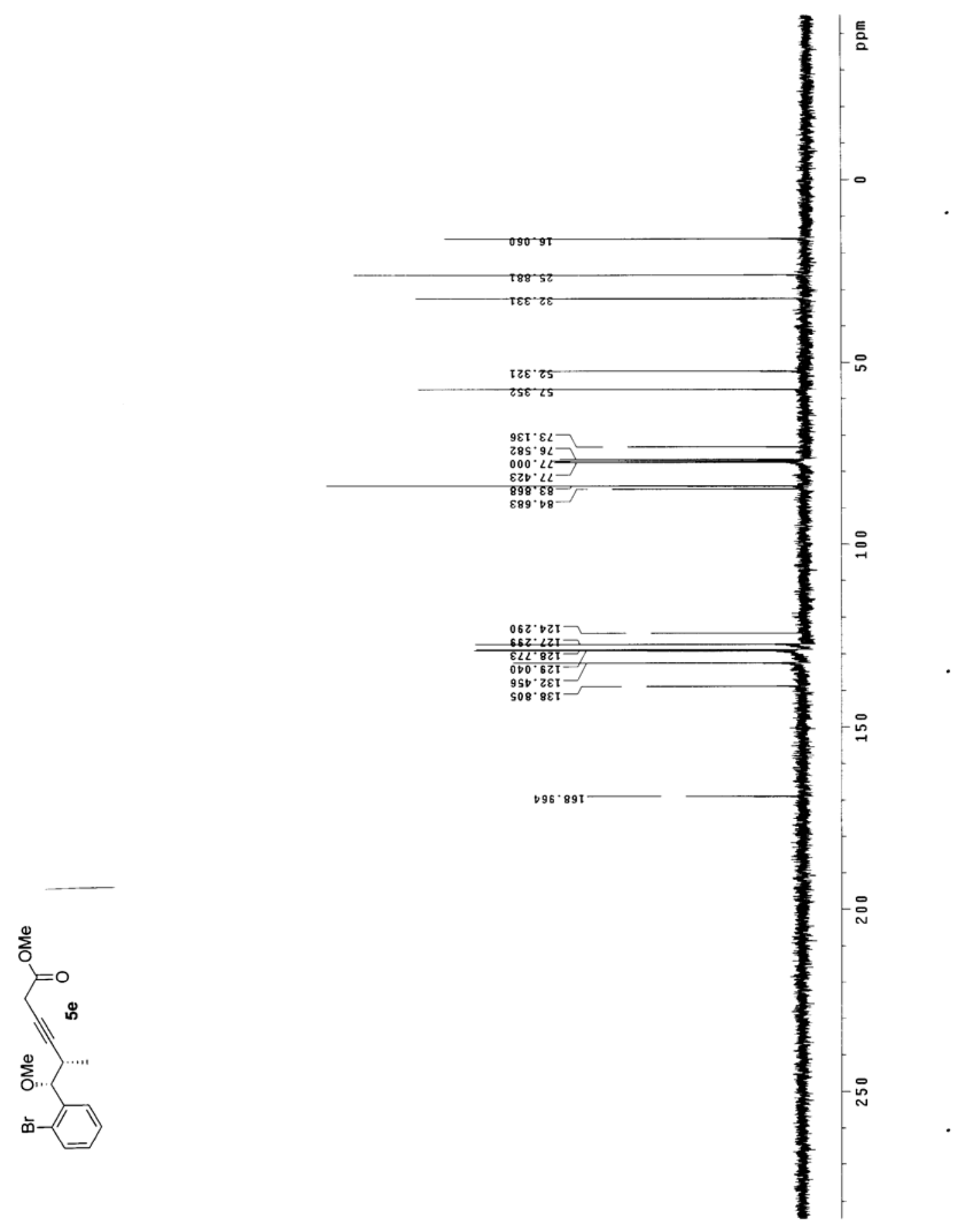




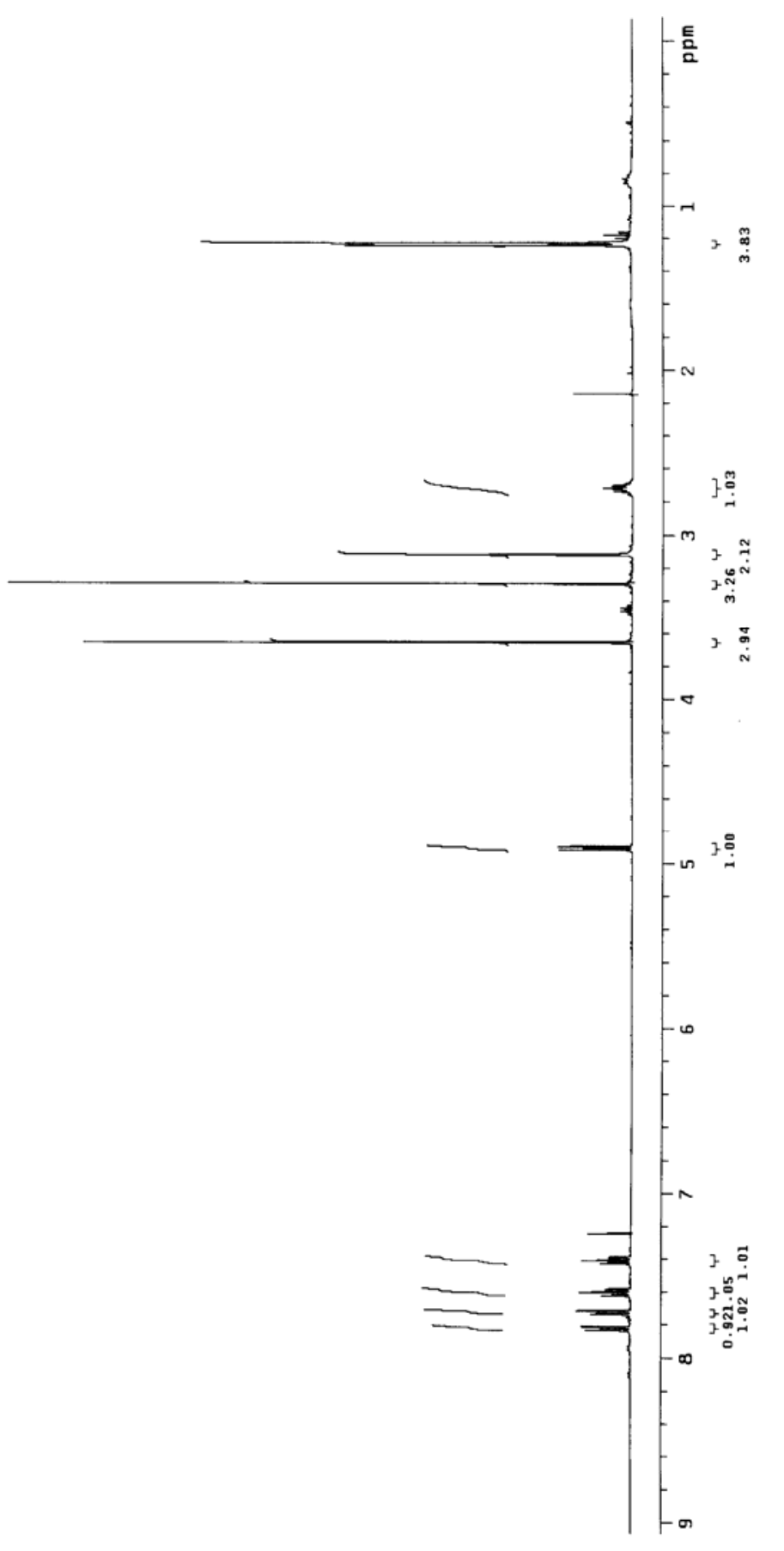




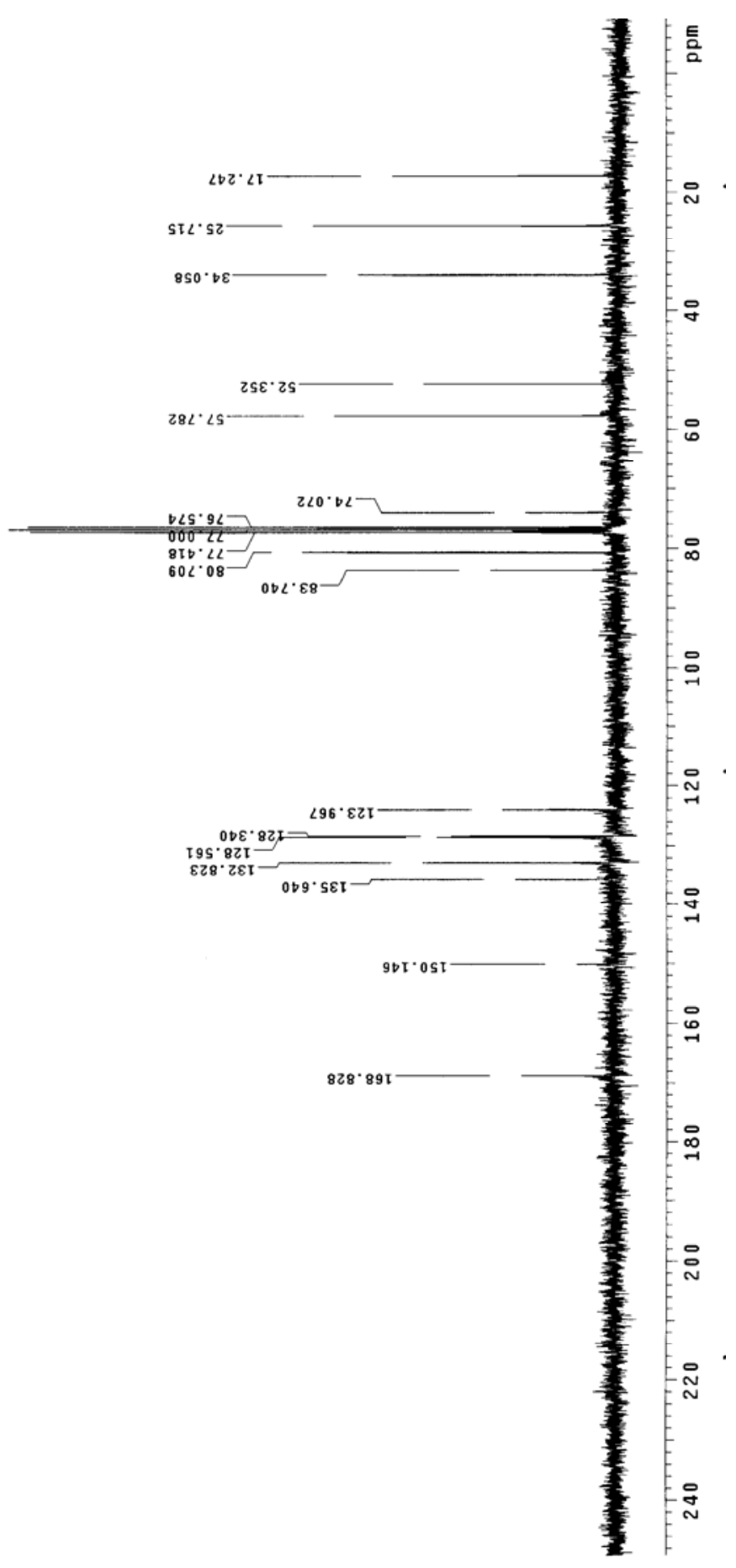




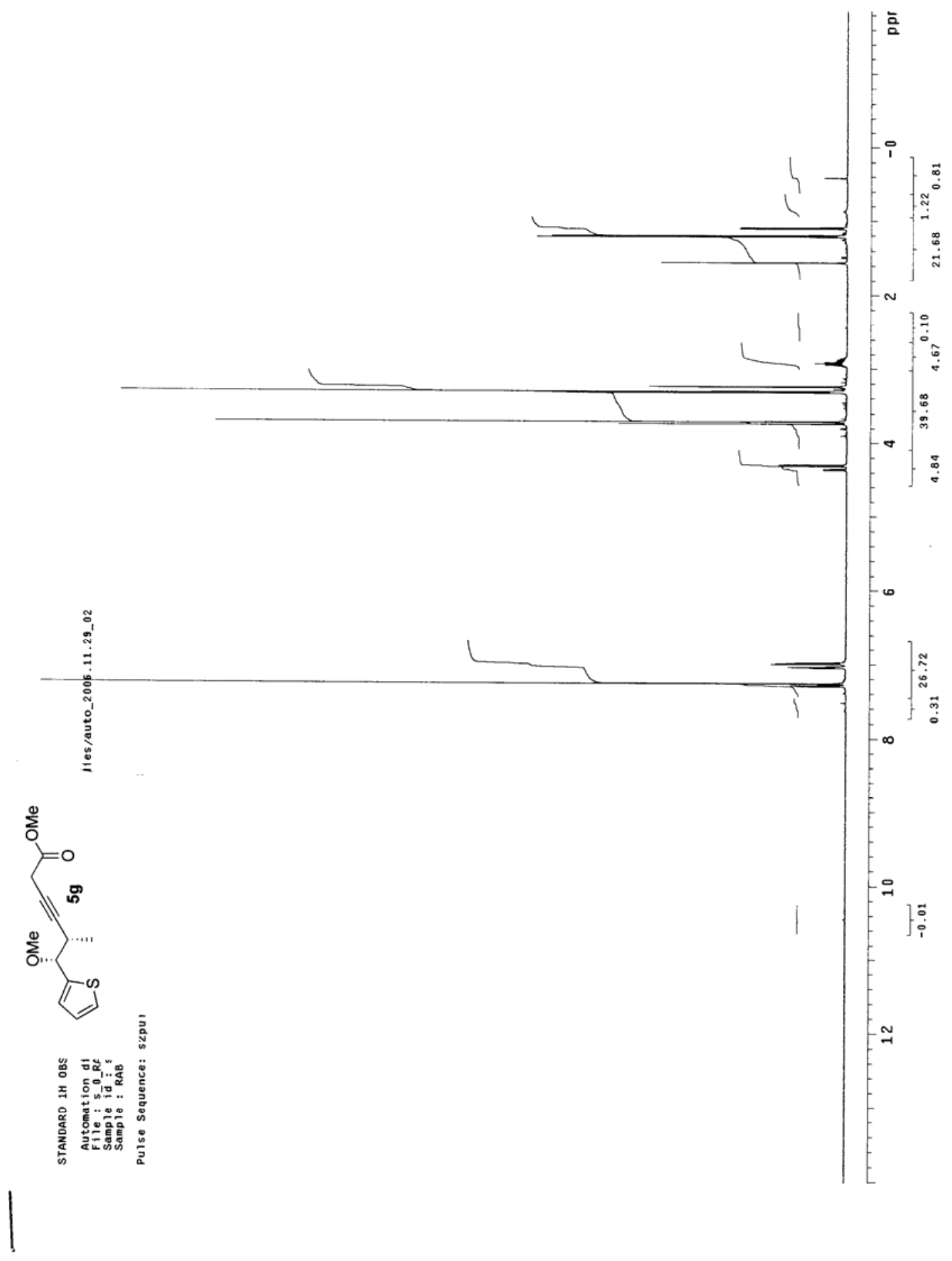




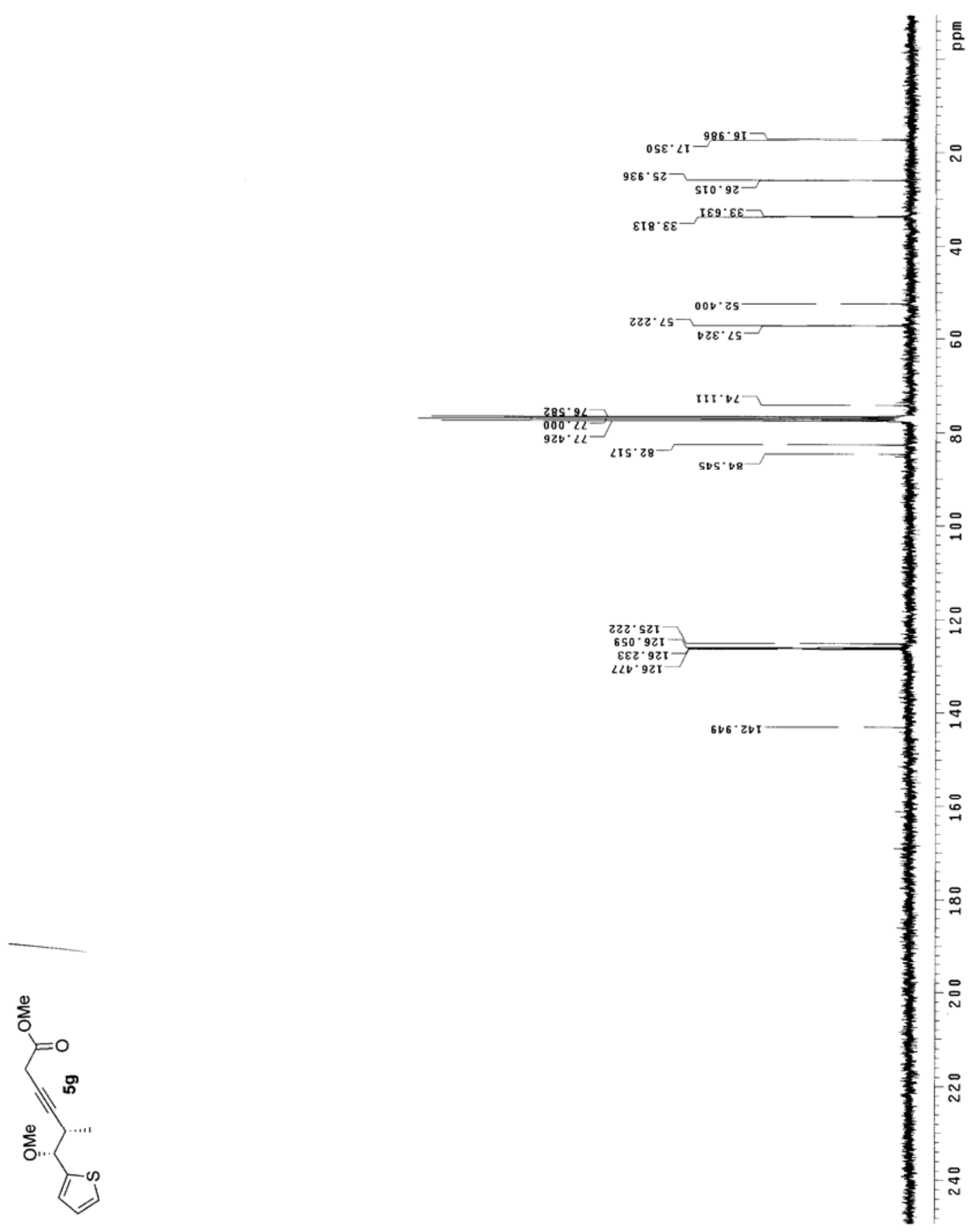




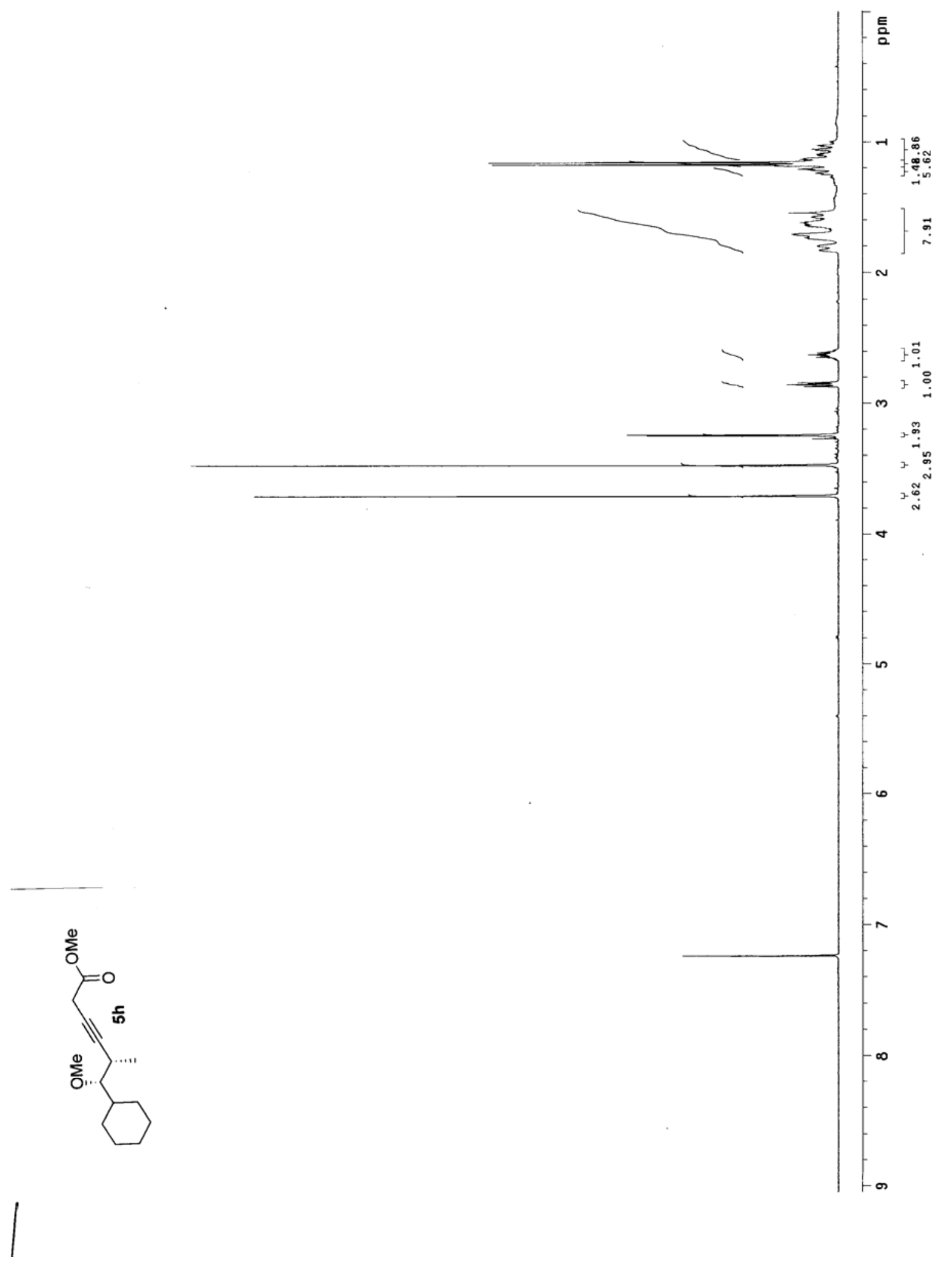




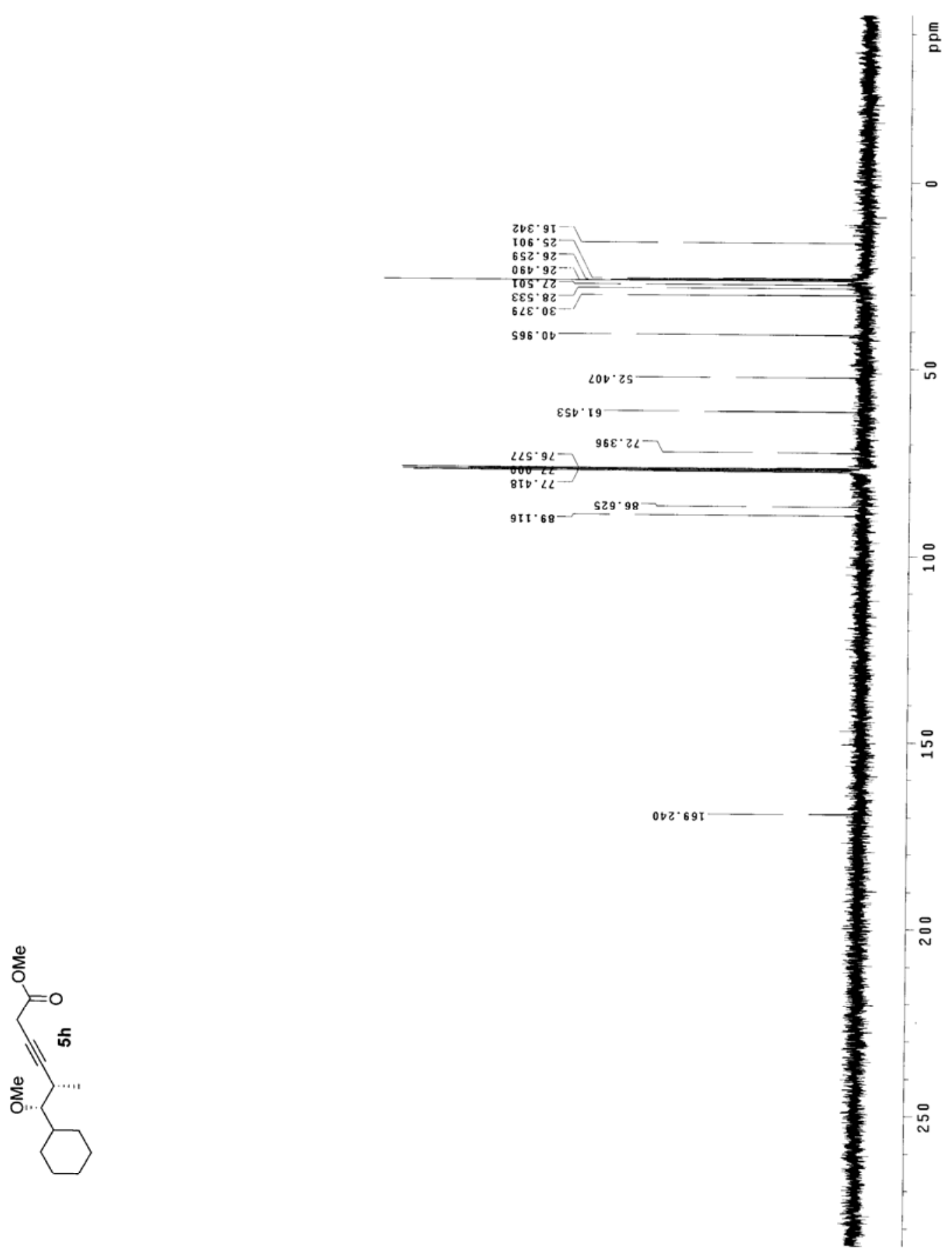




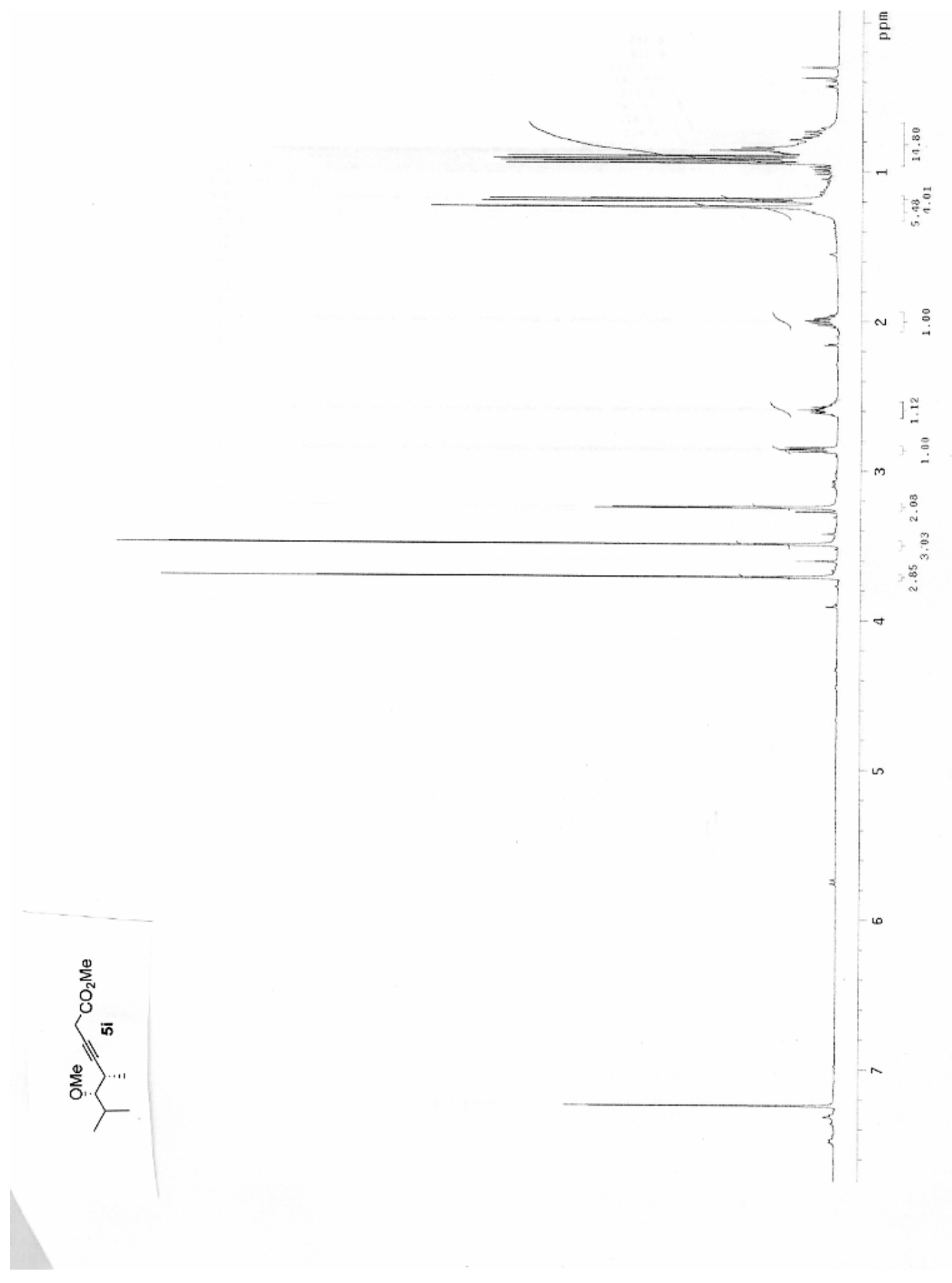




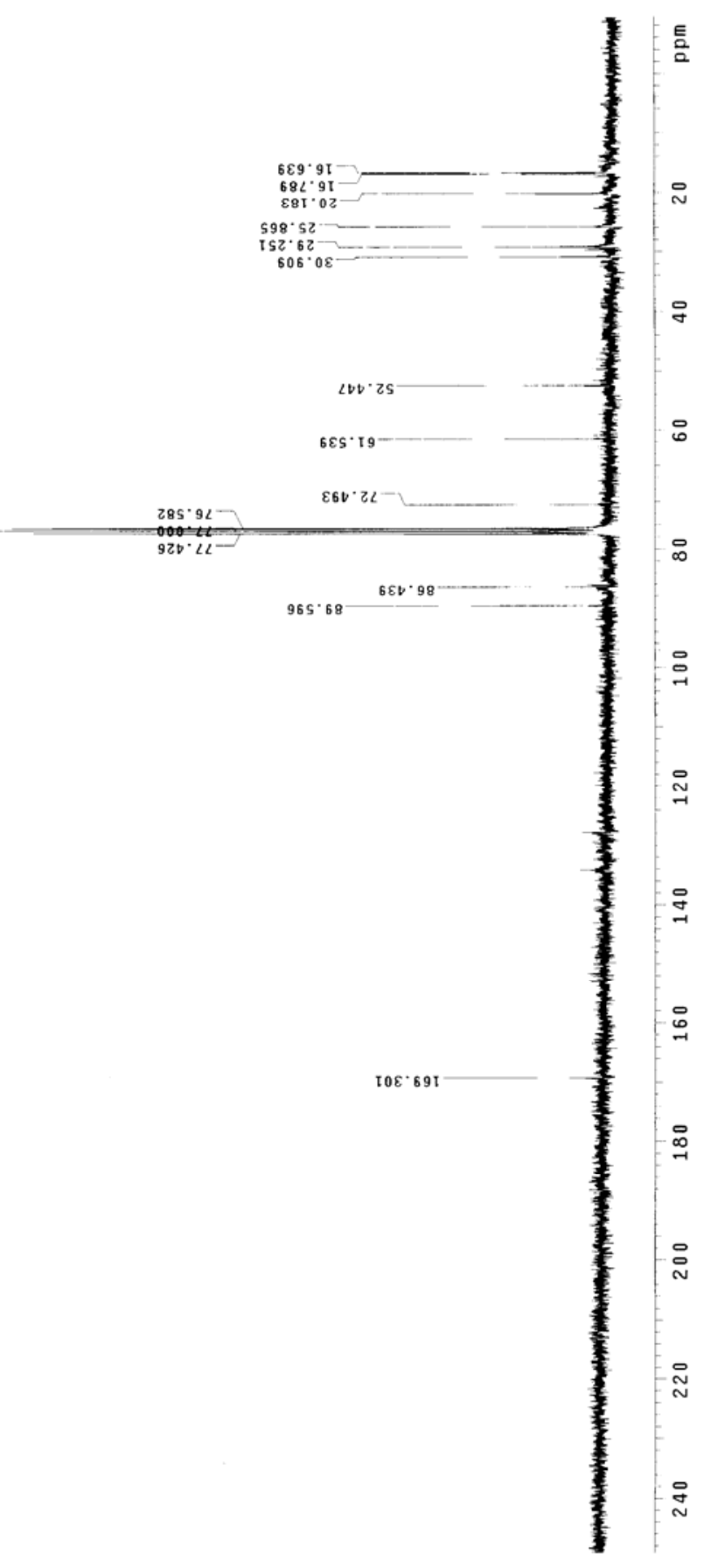




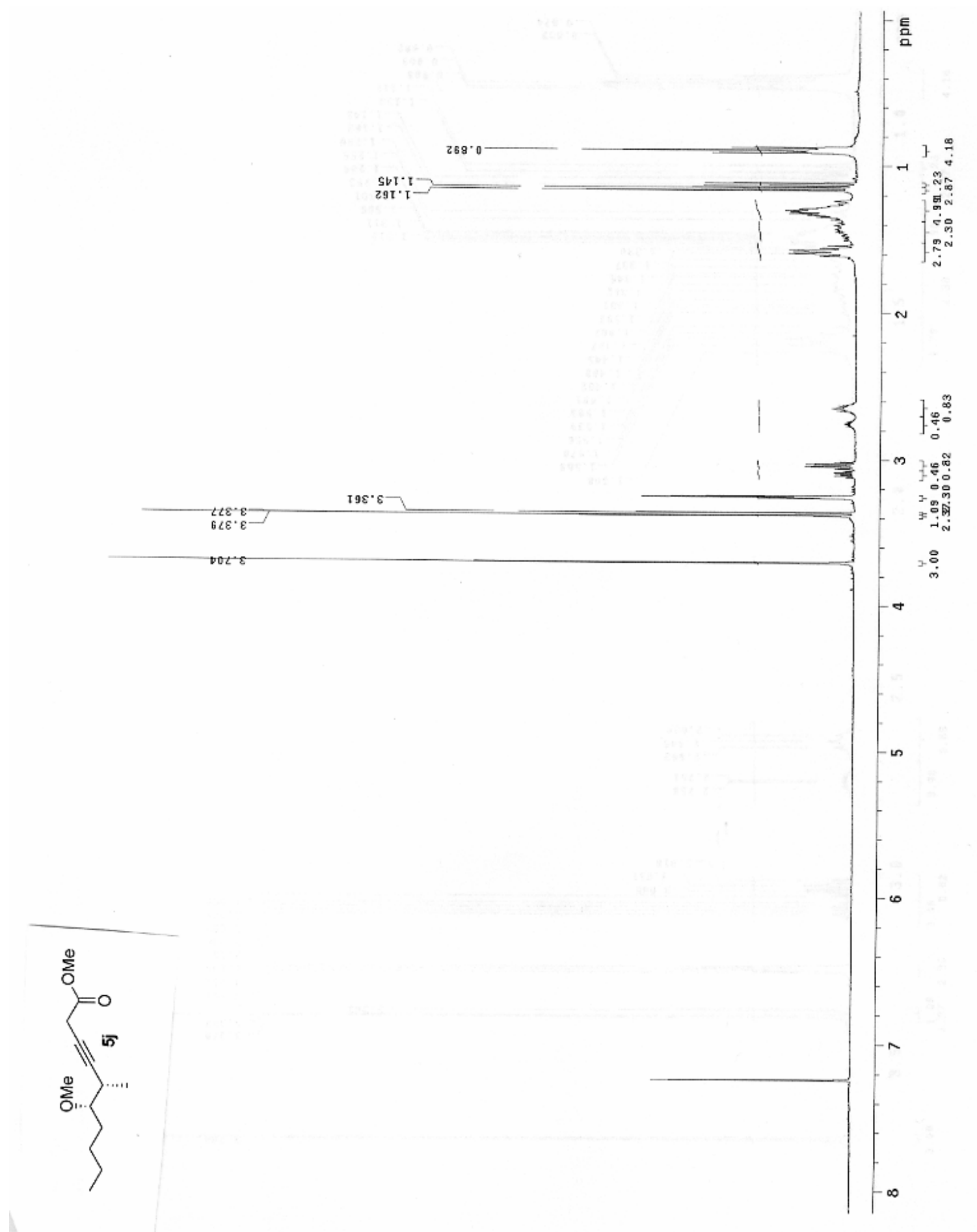




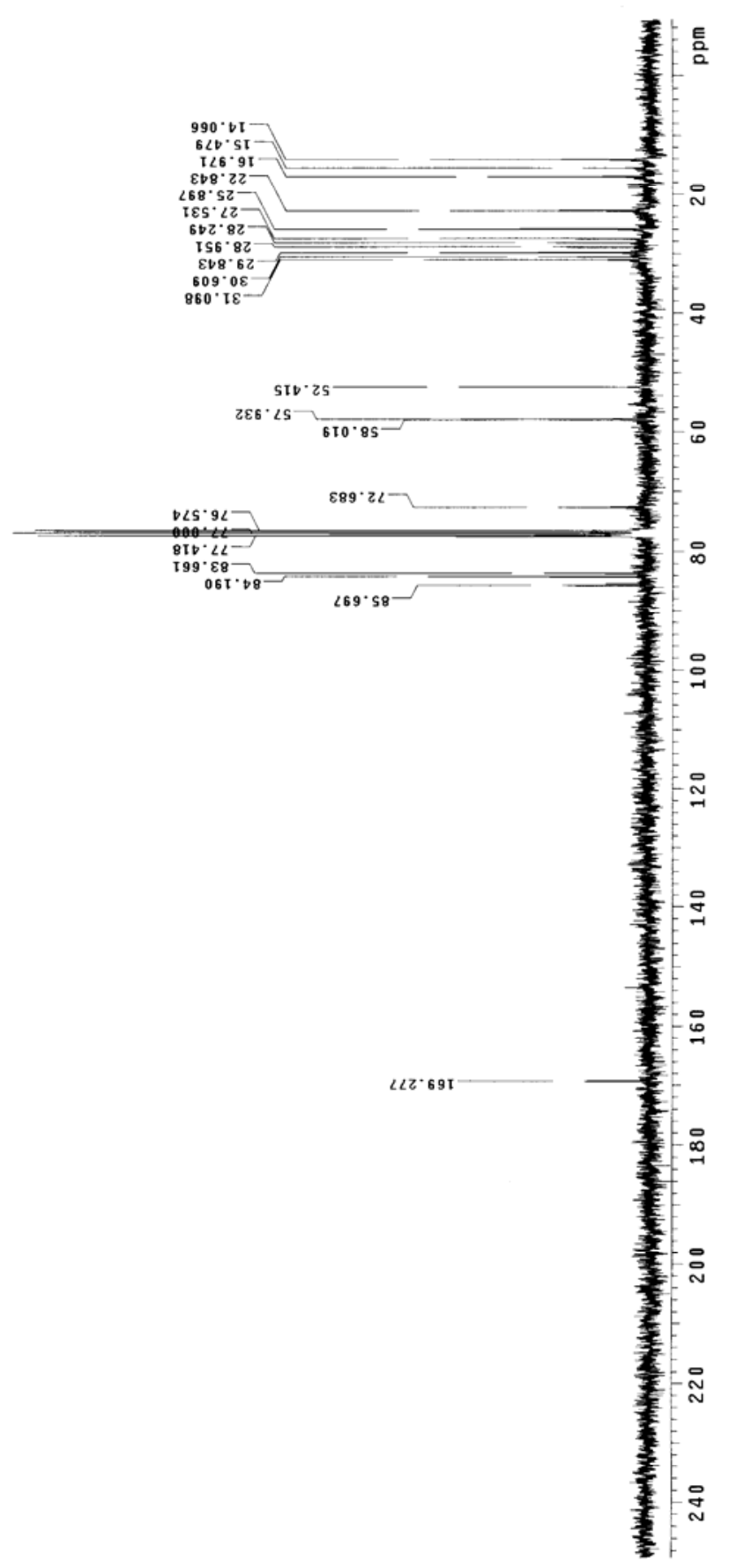




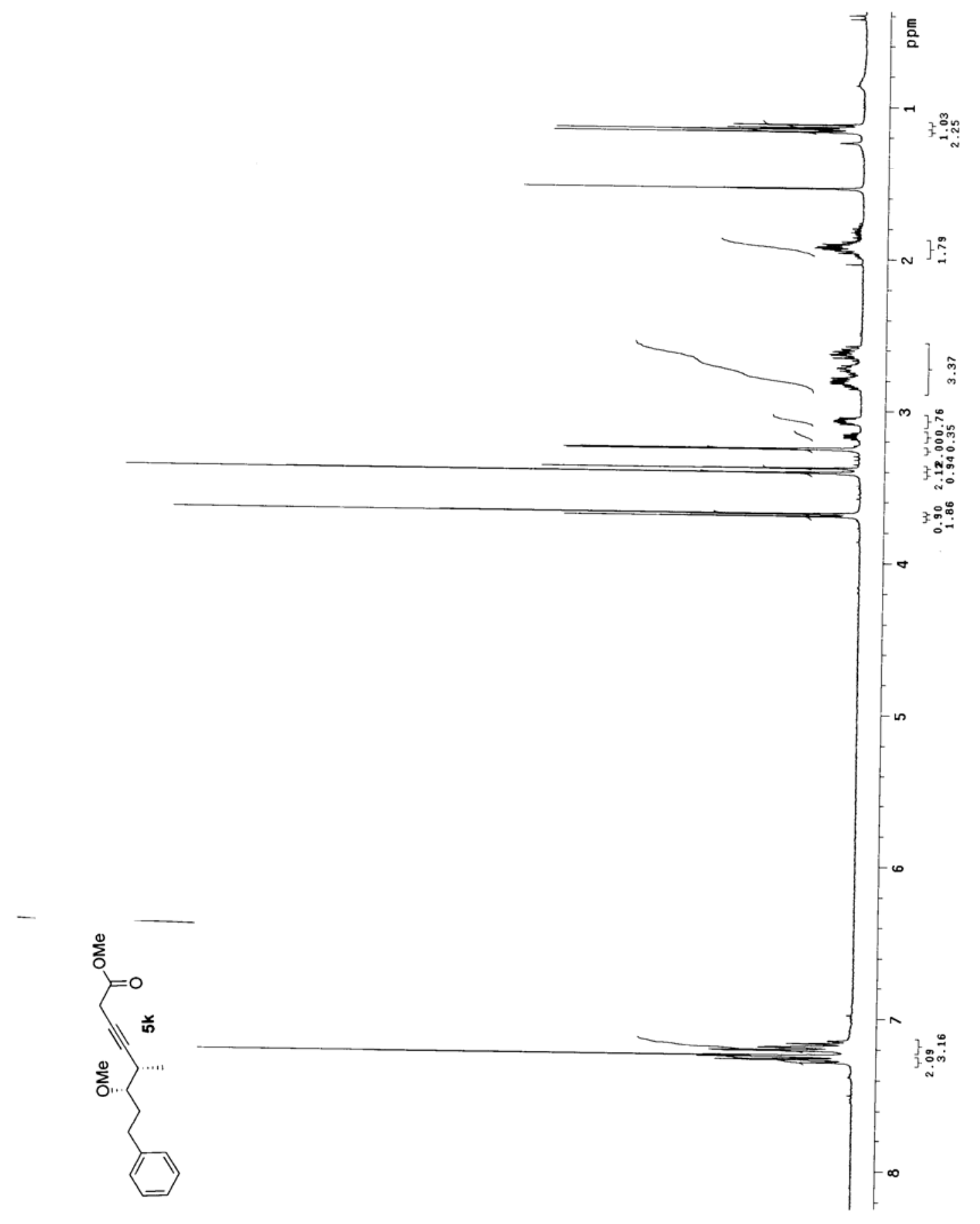




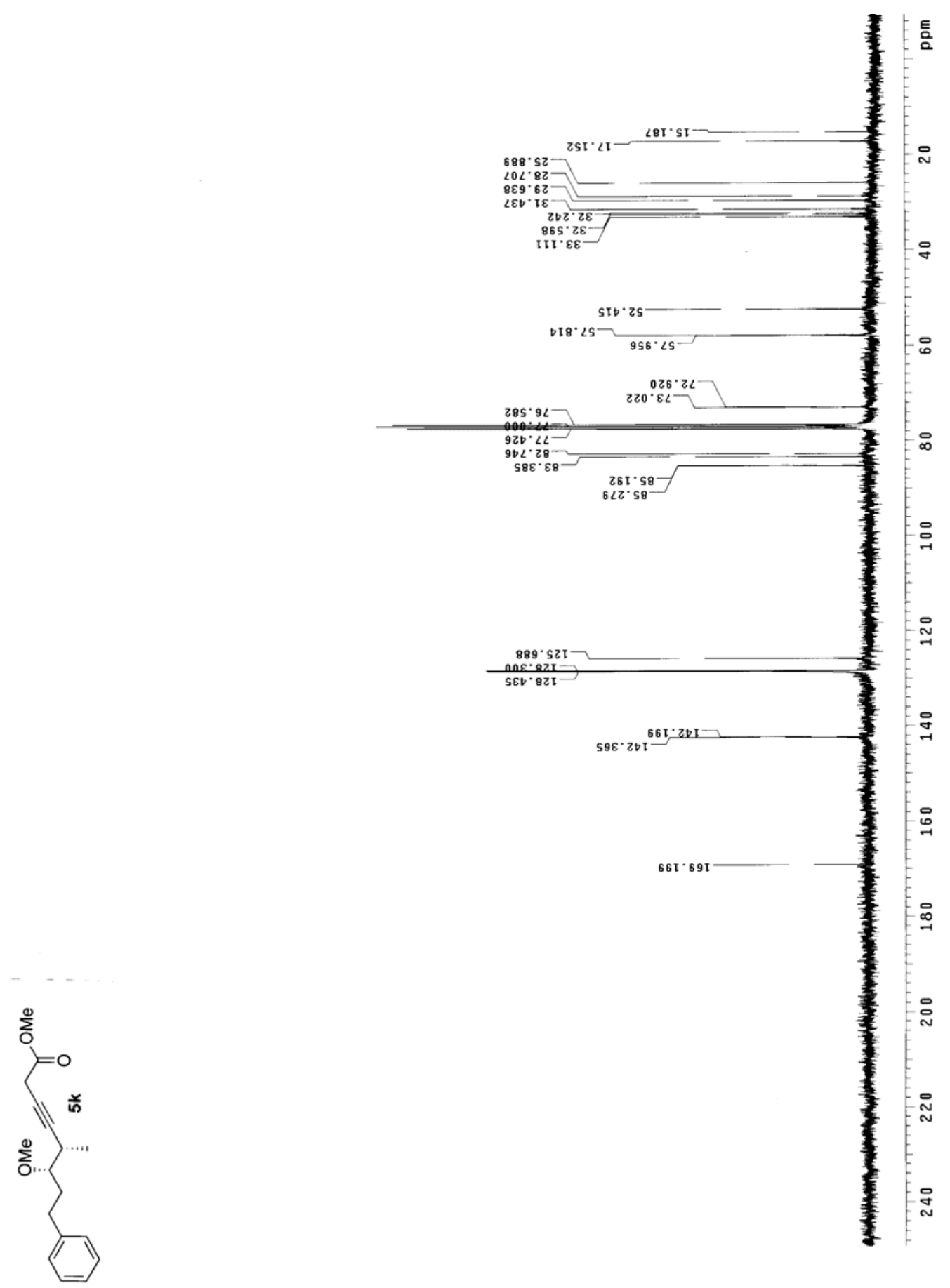


I

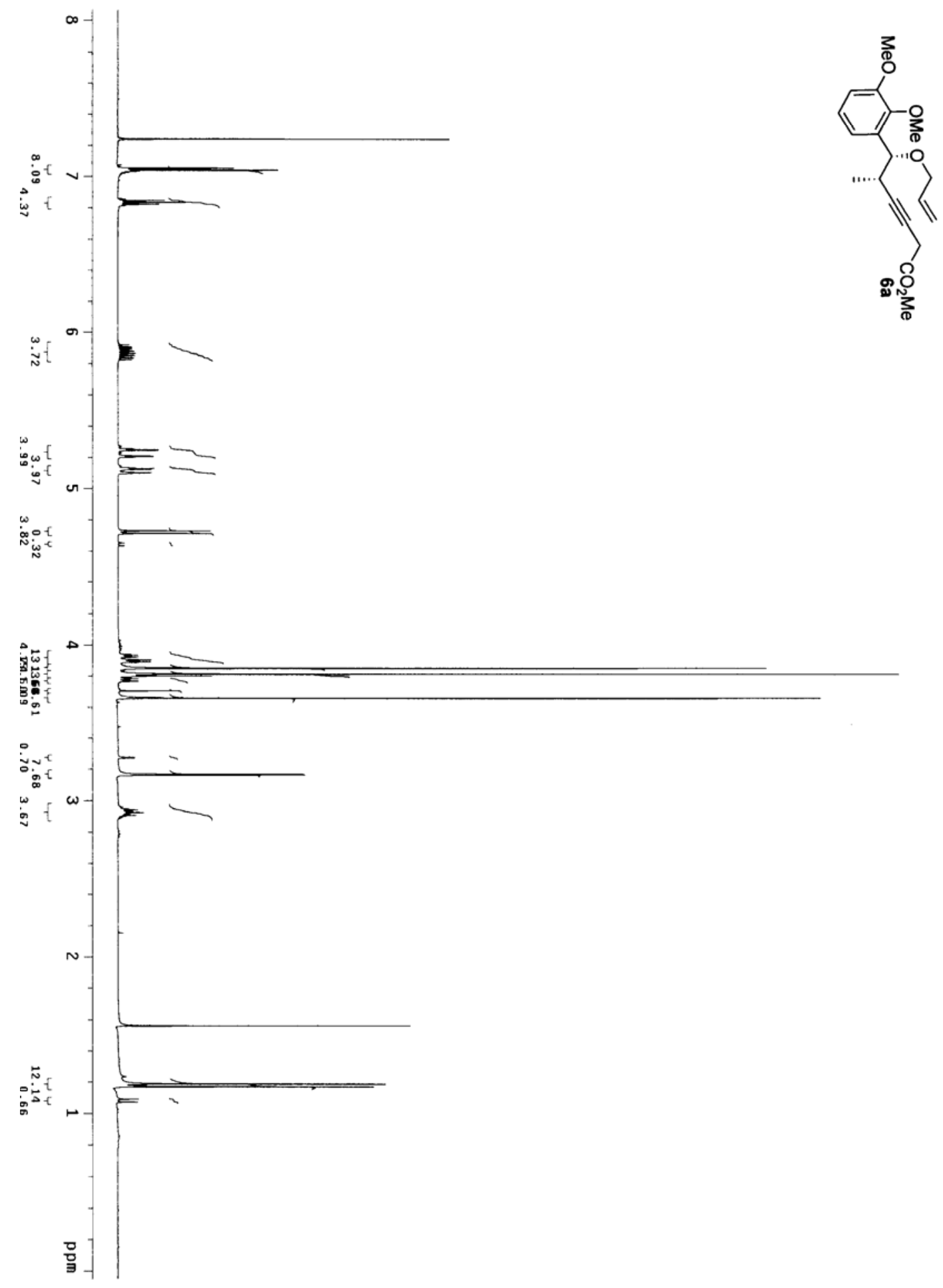



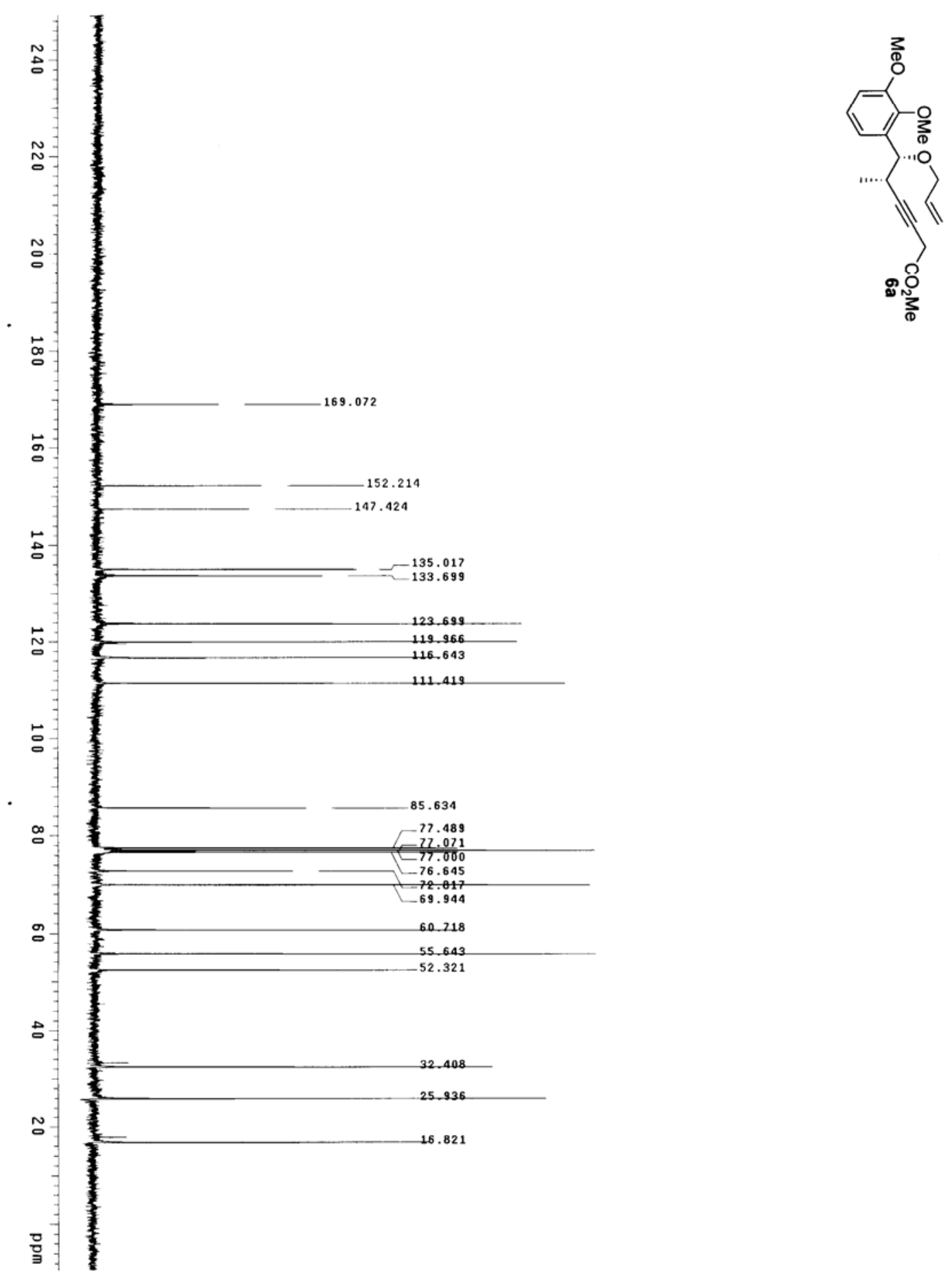

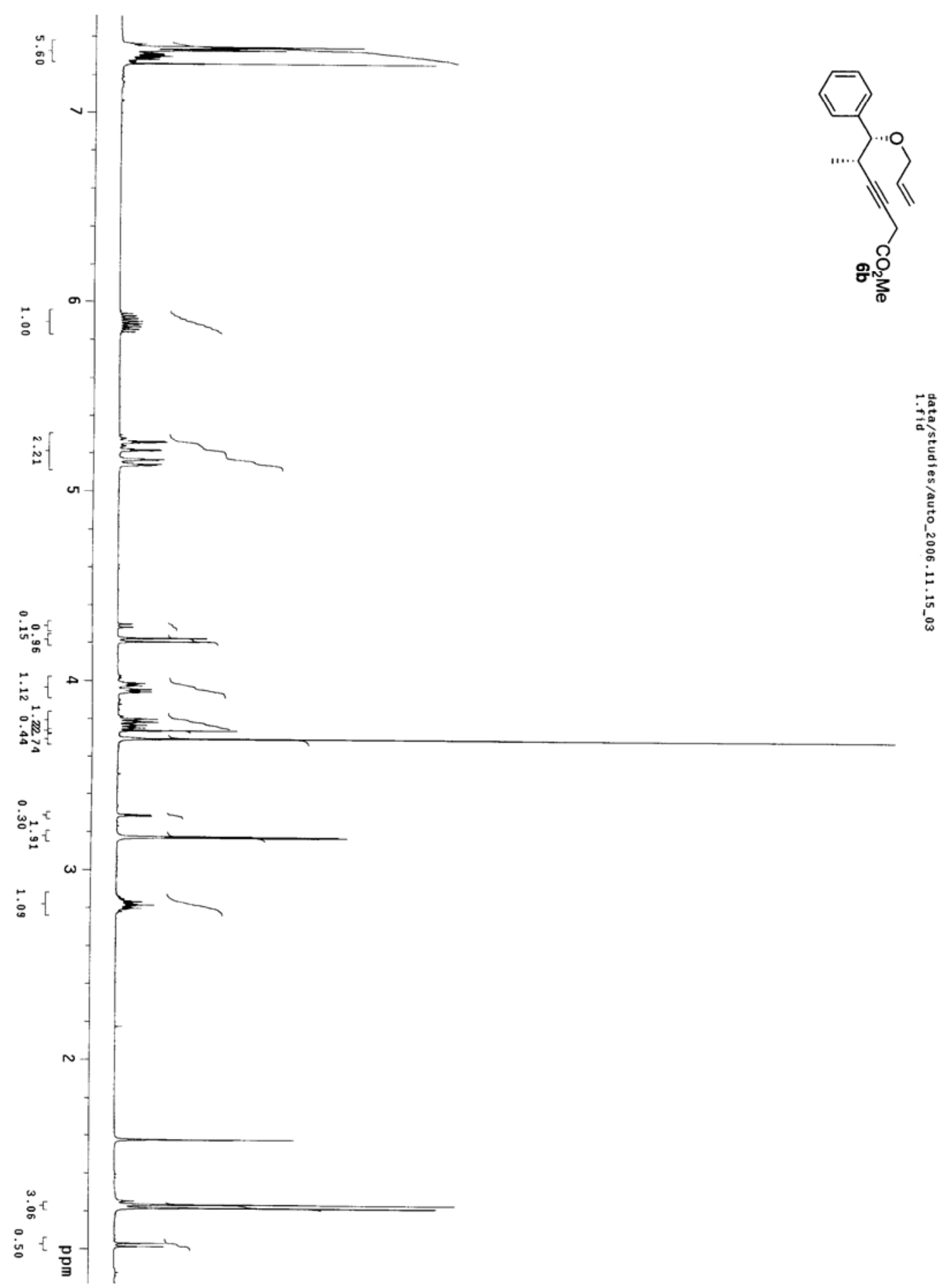

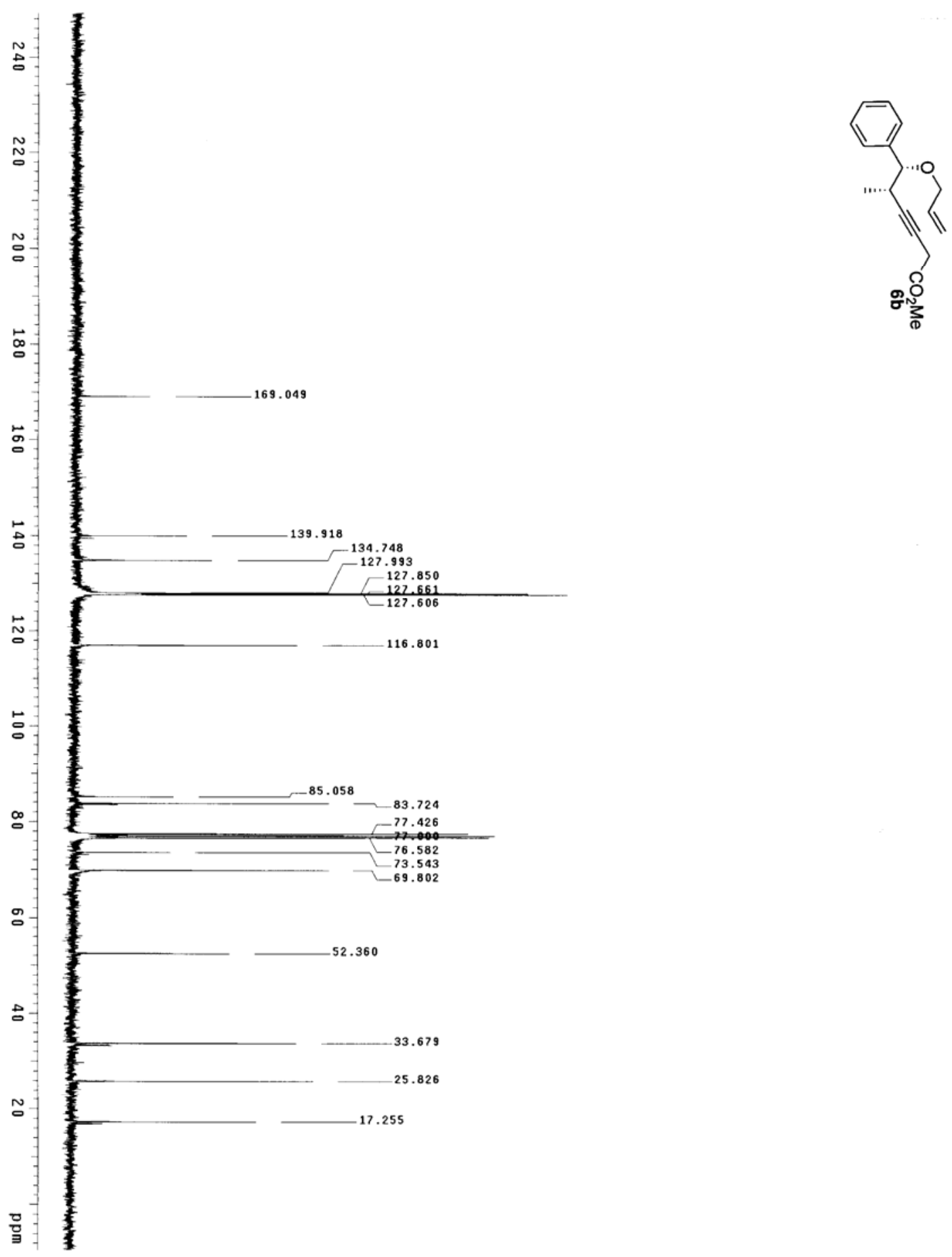

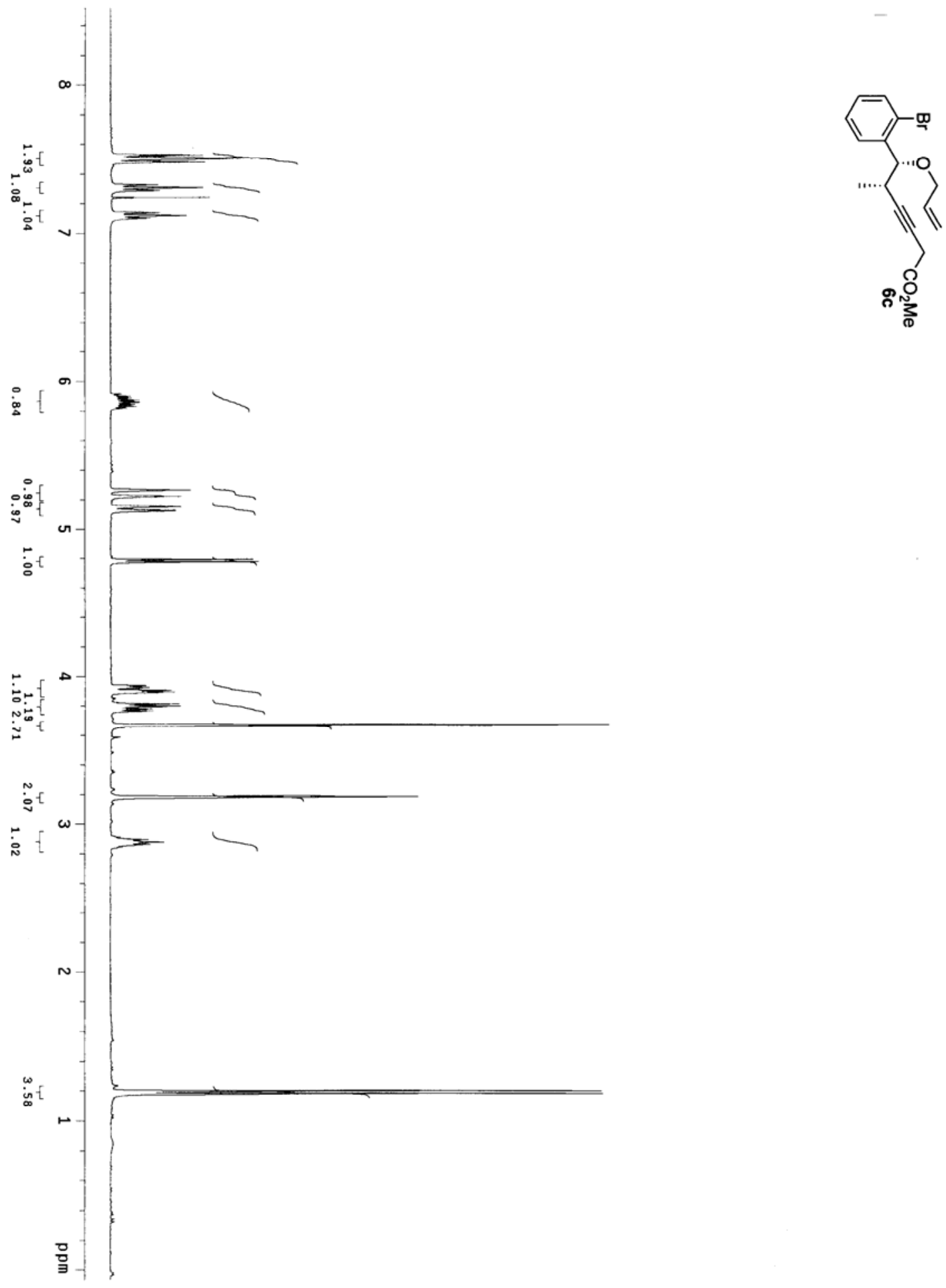


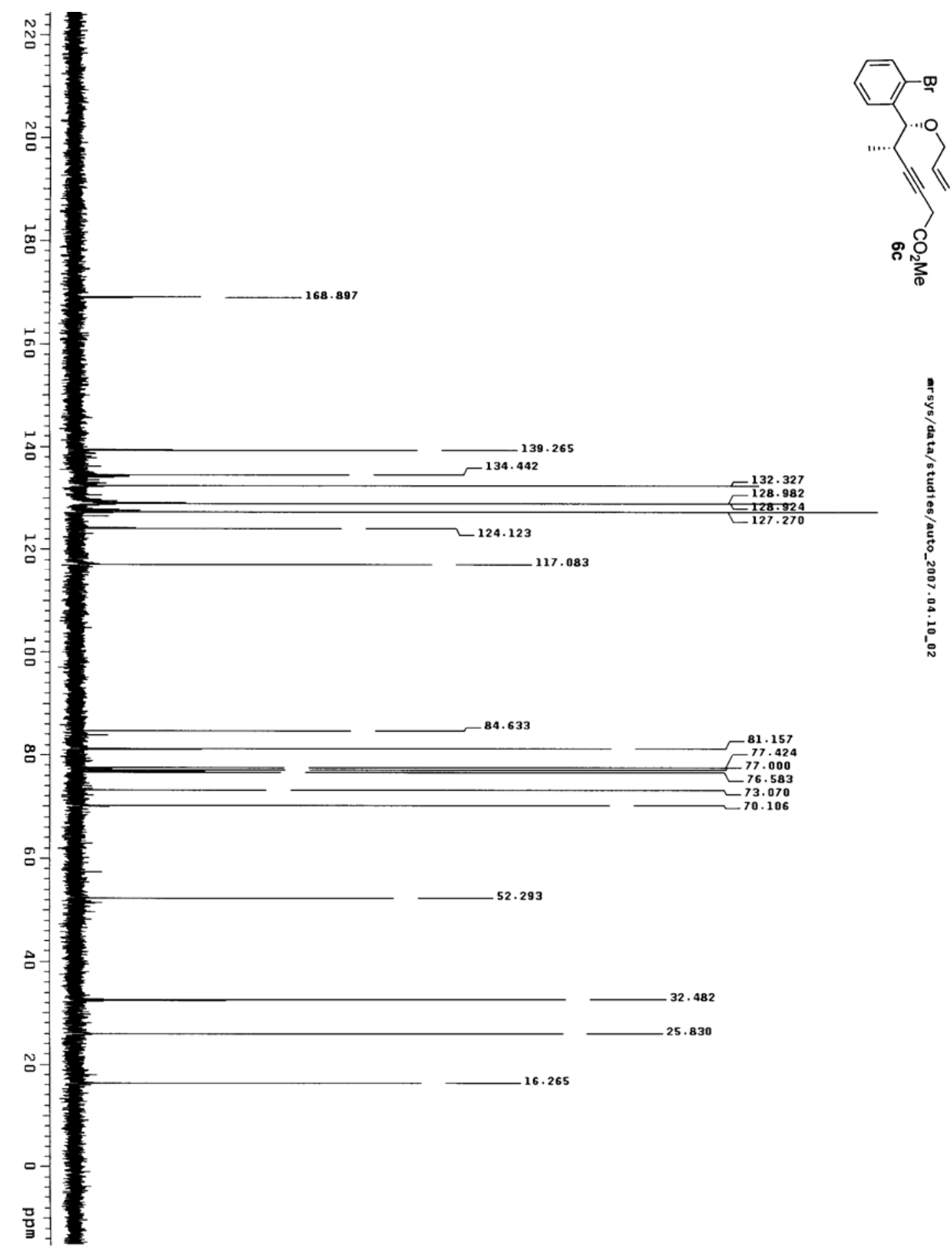




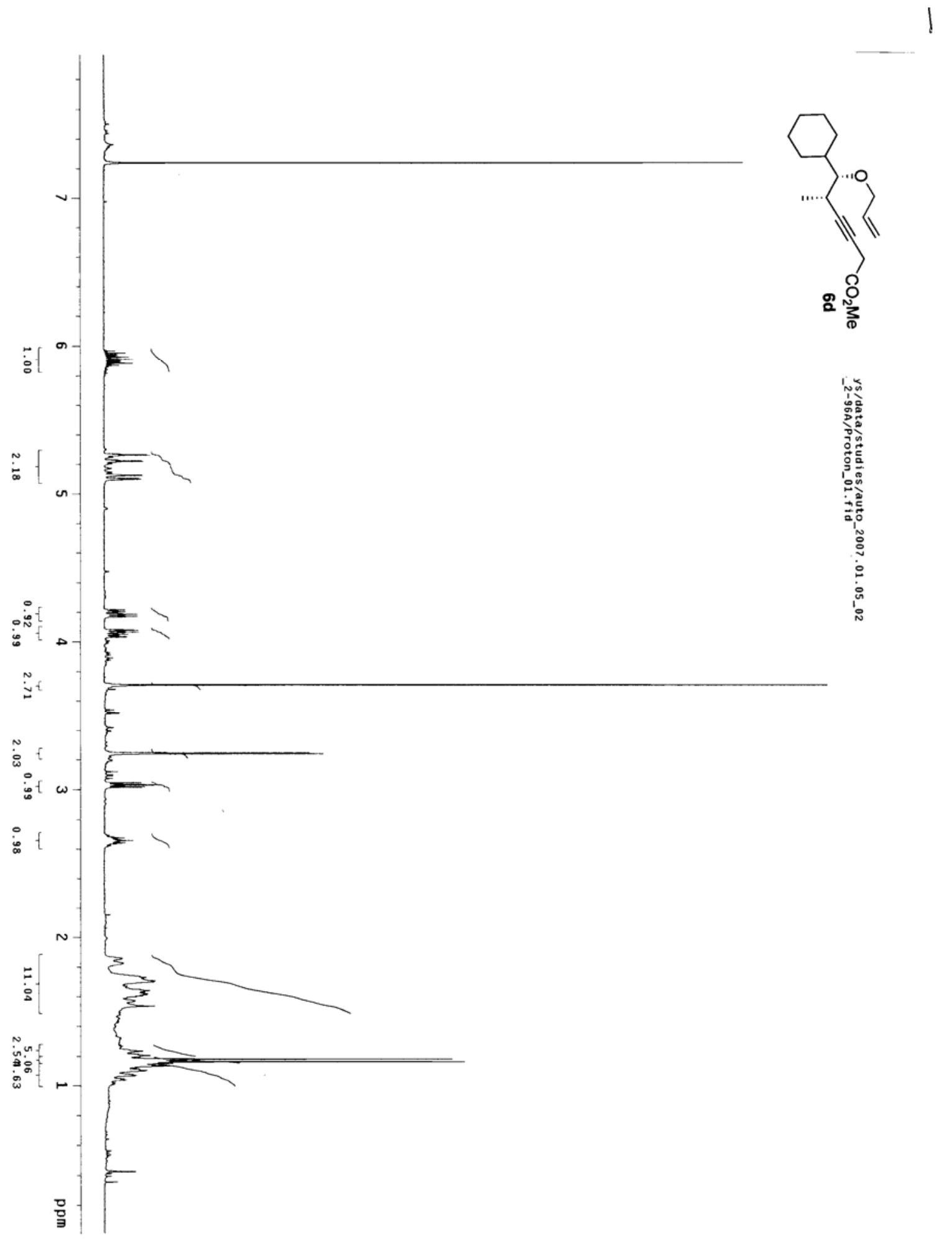

SI-59 

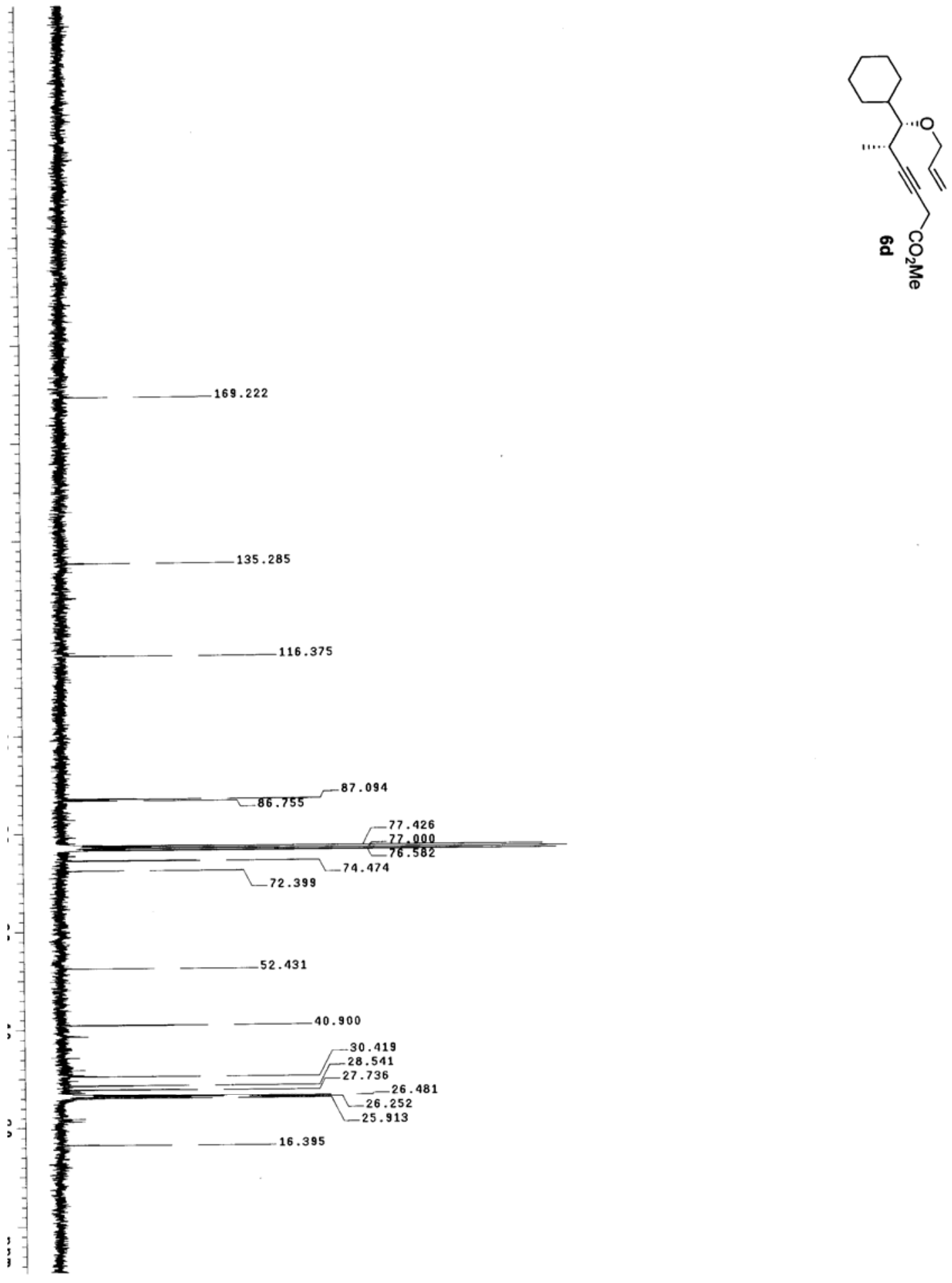


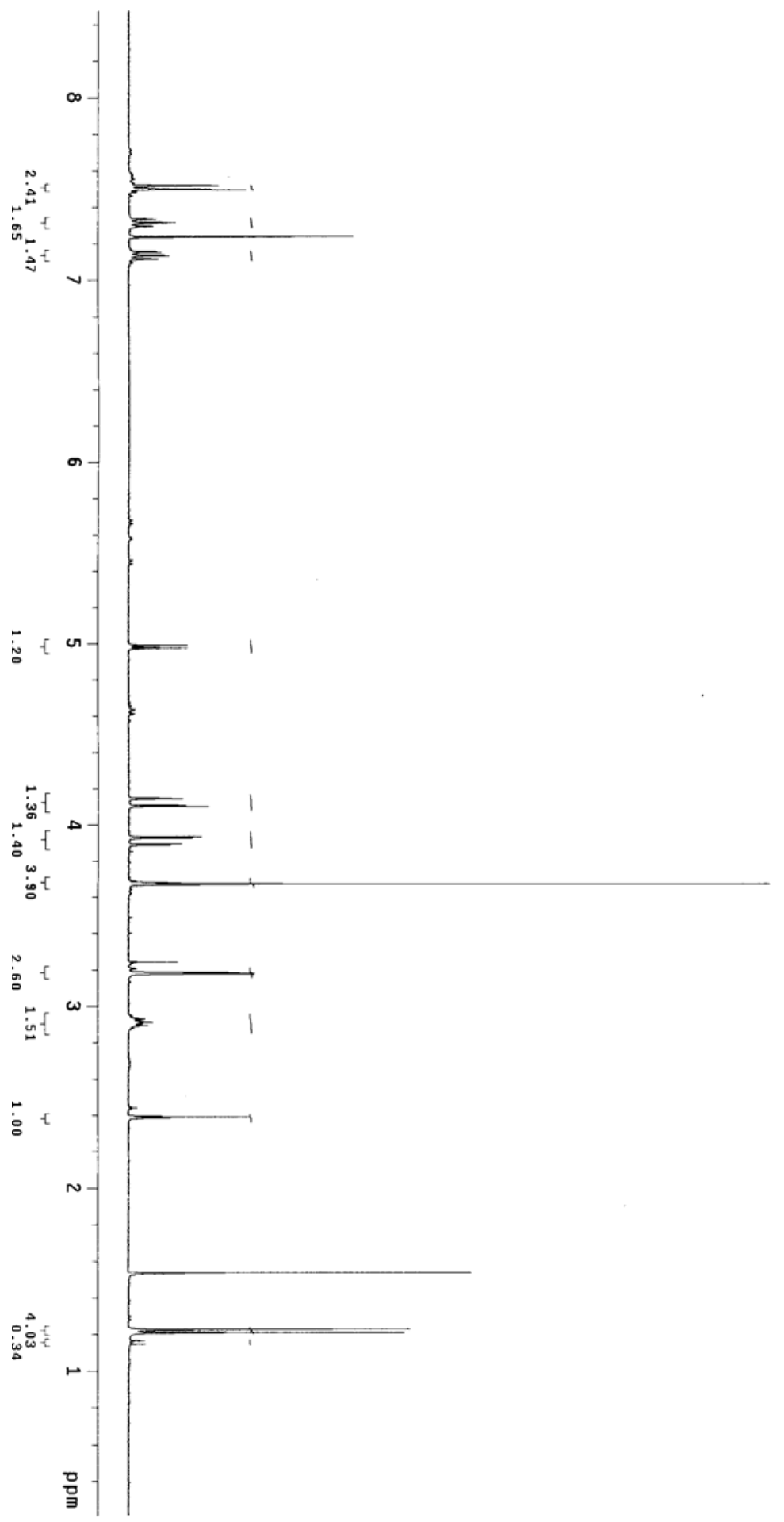

-

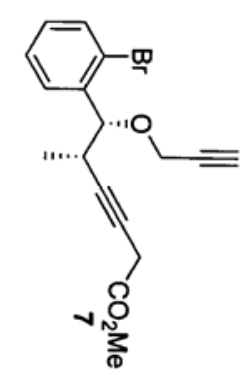

SI-61 

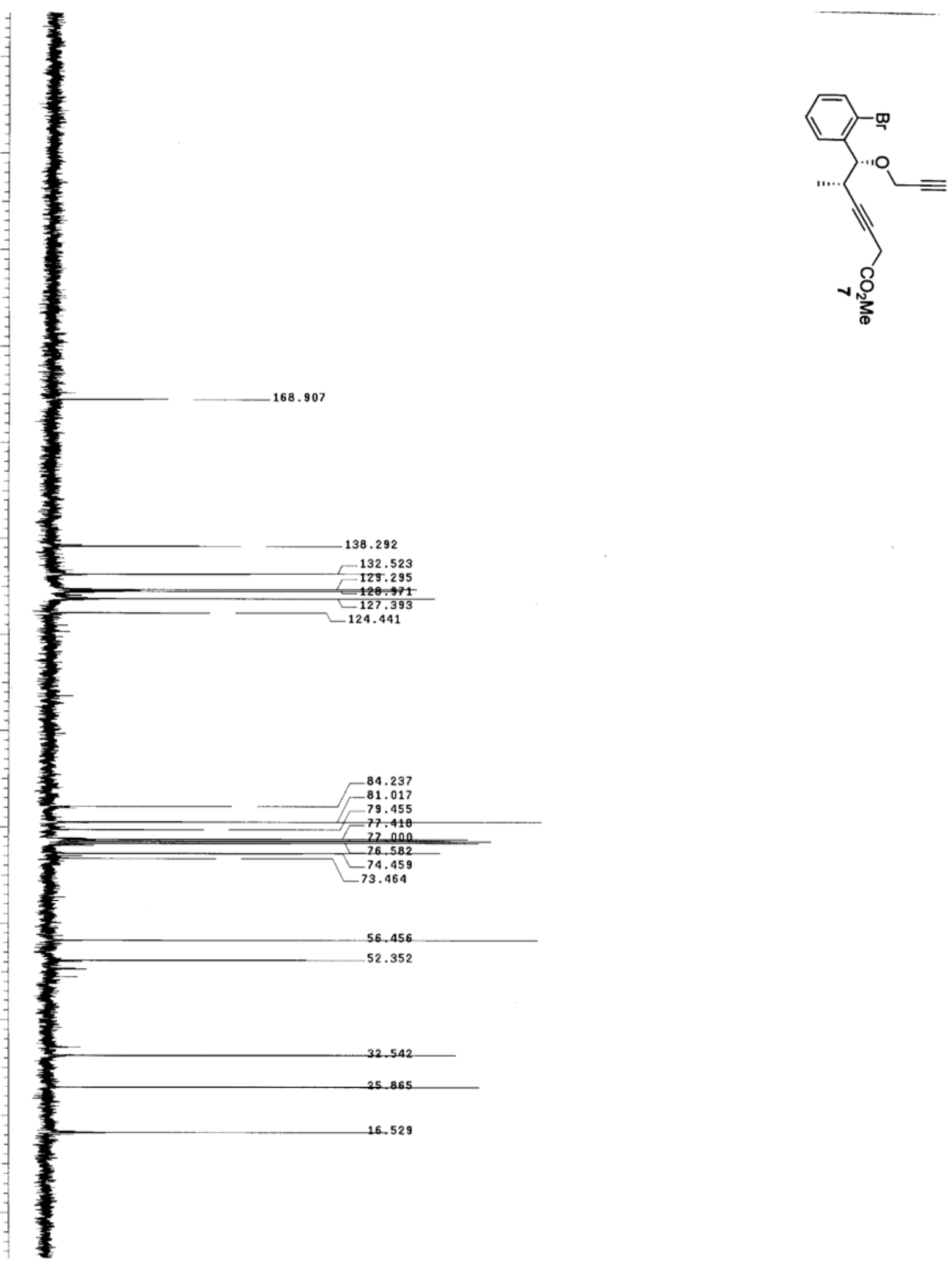

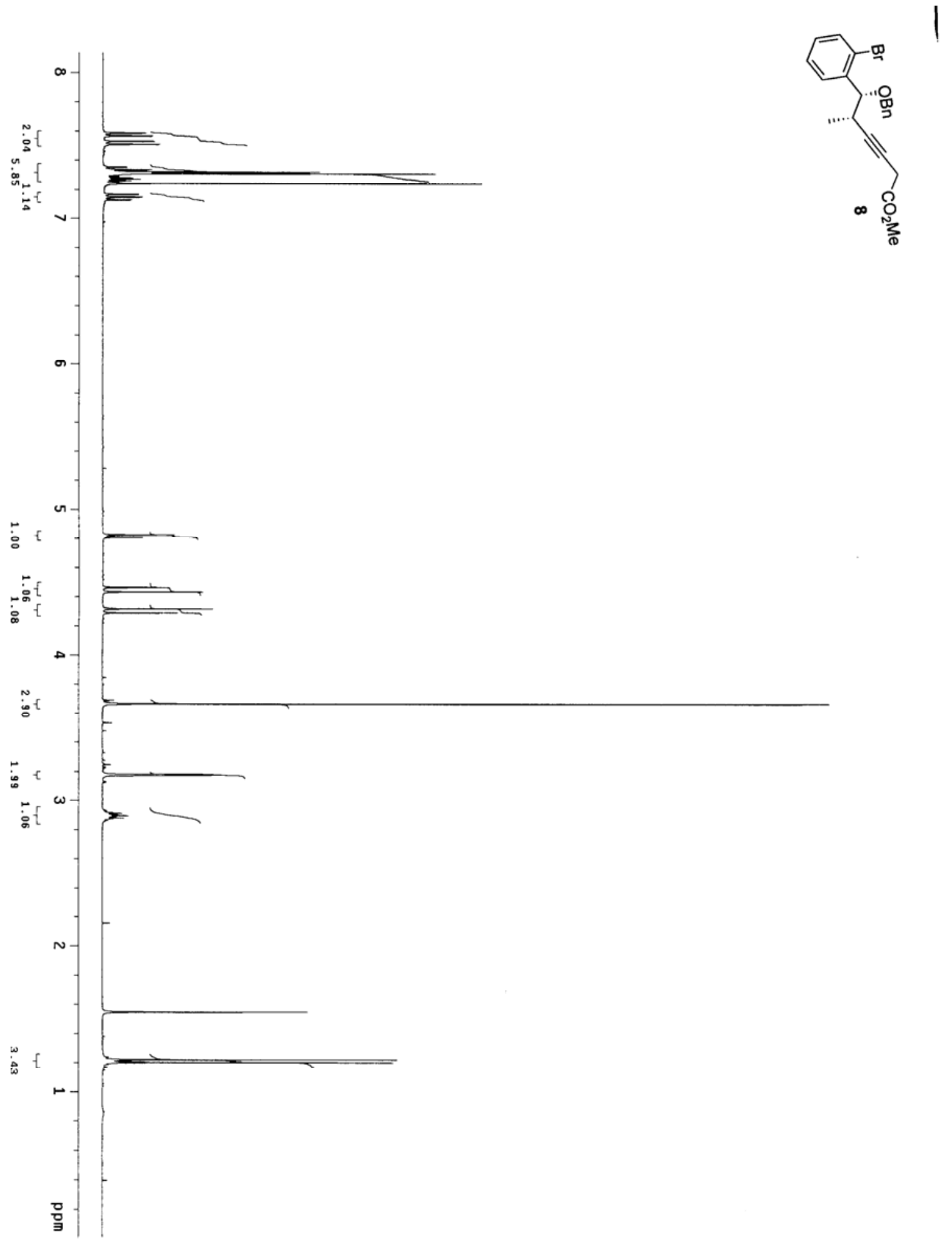

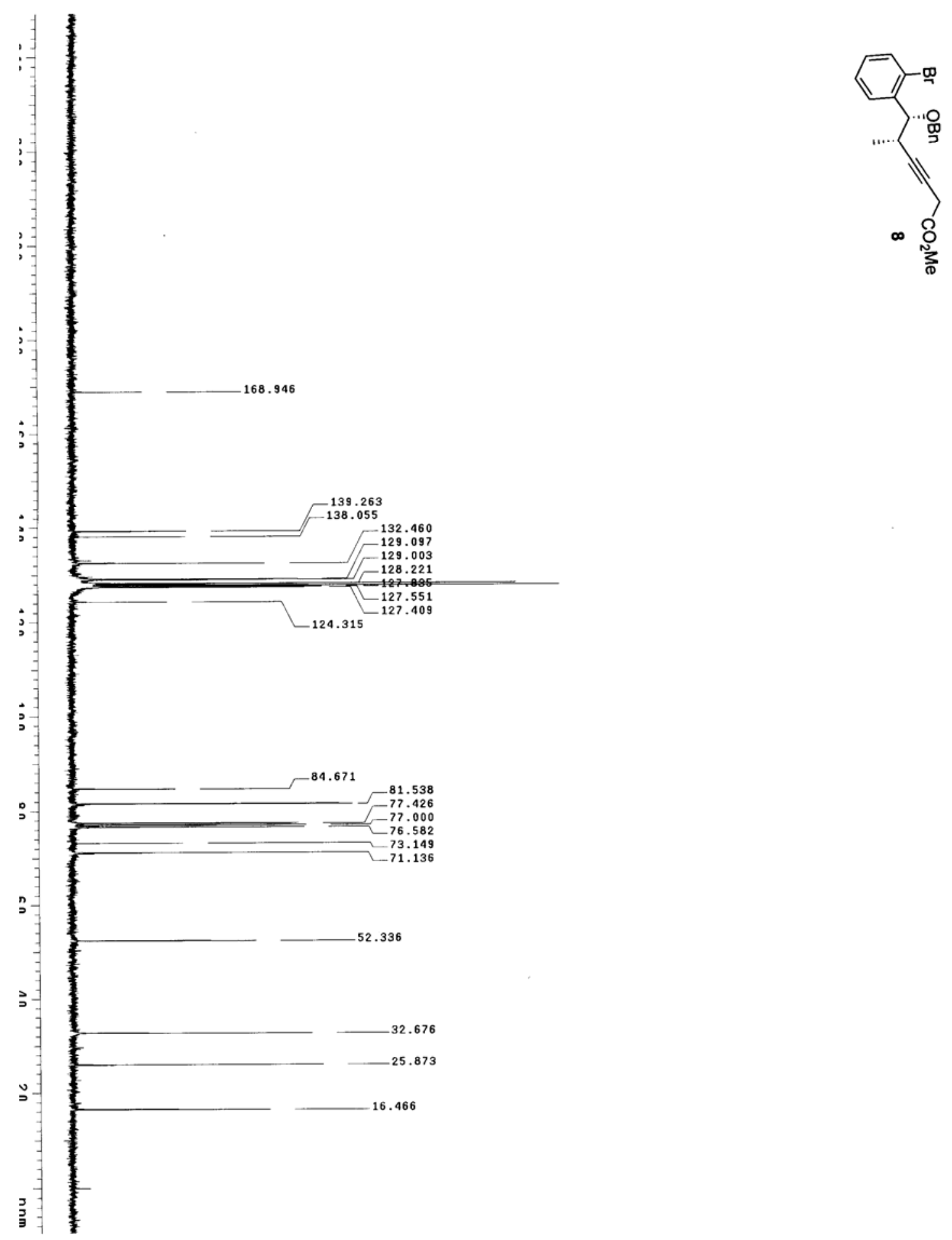


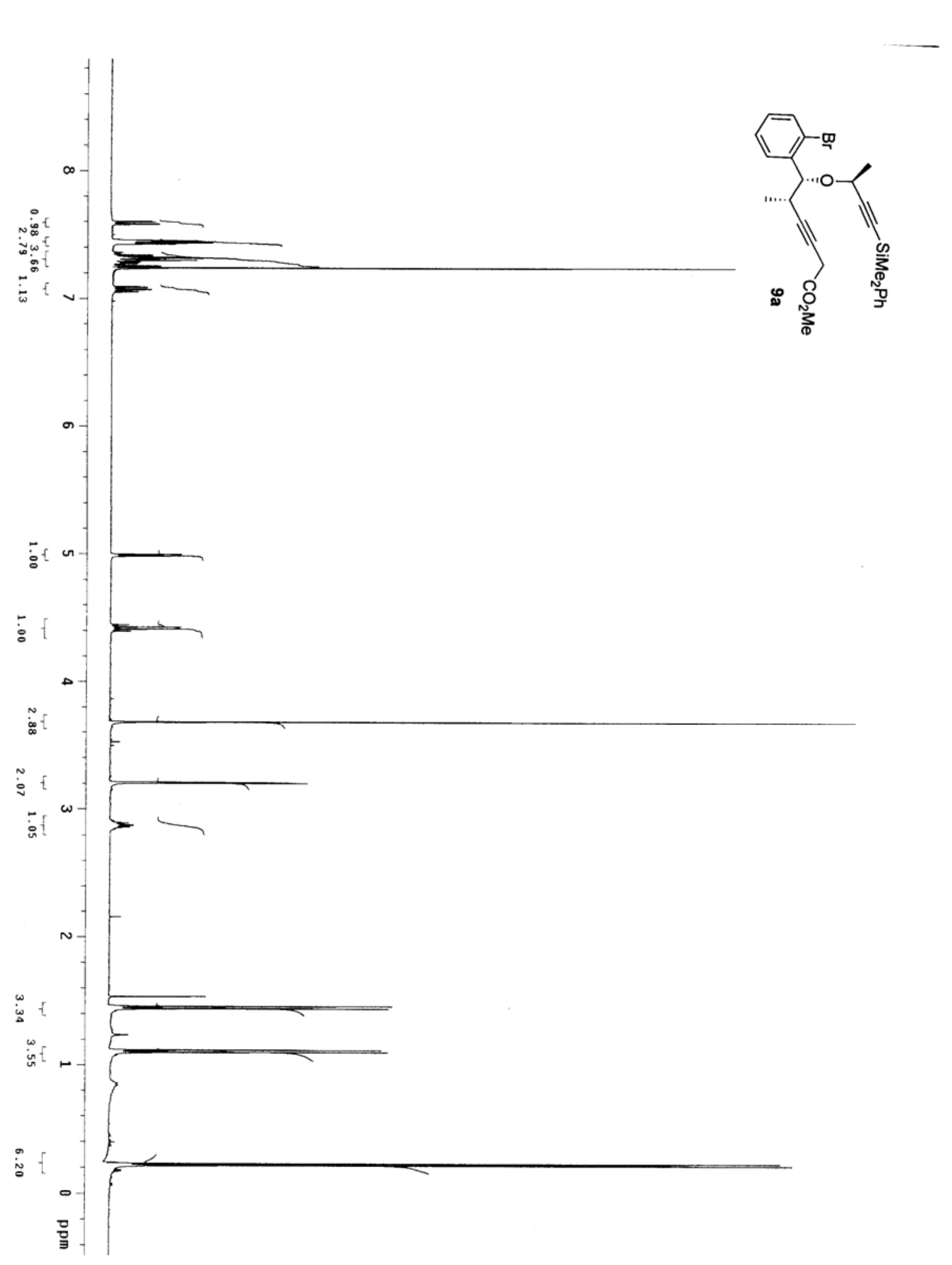



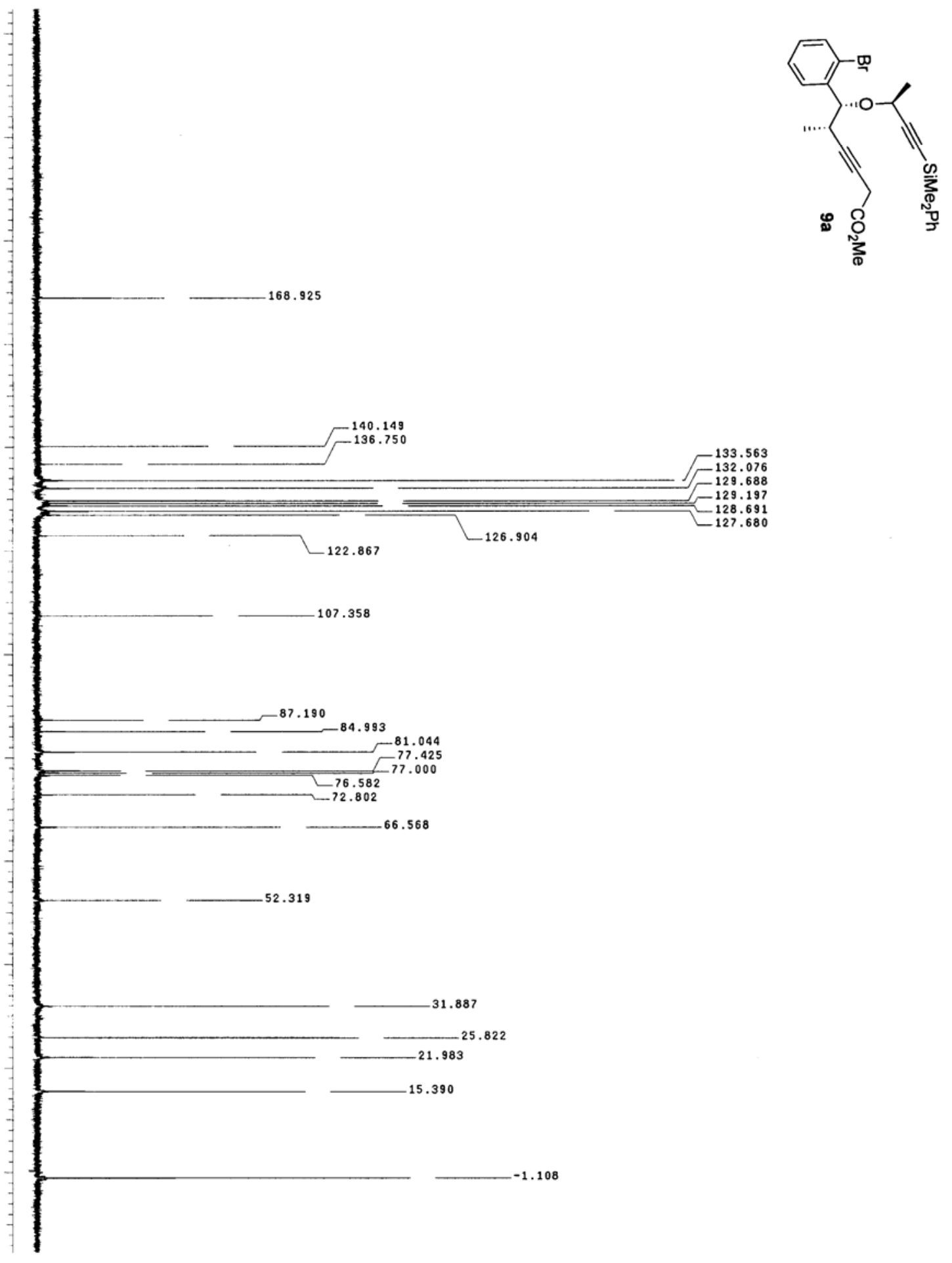


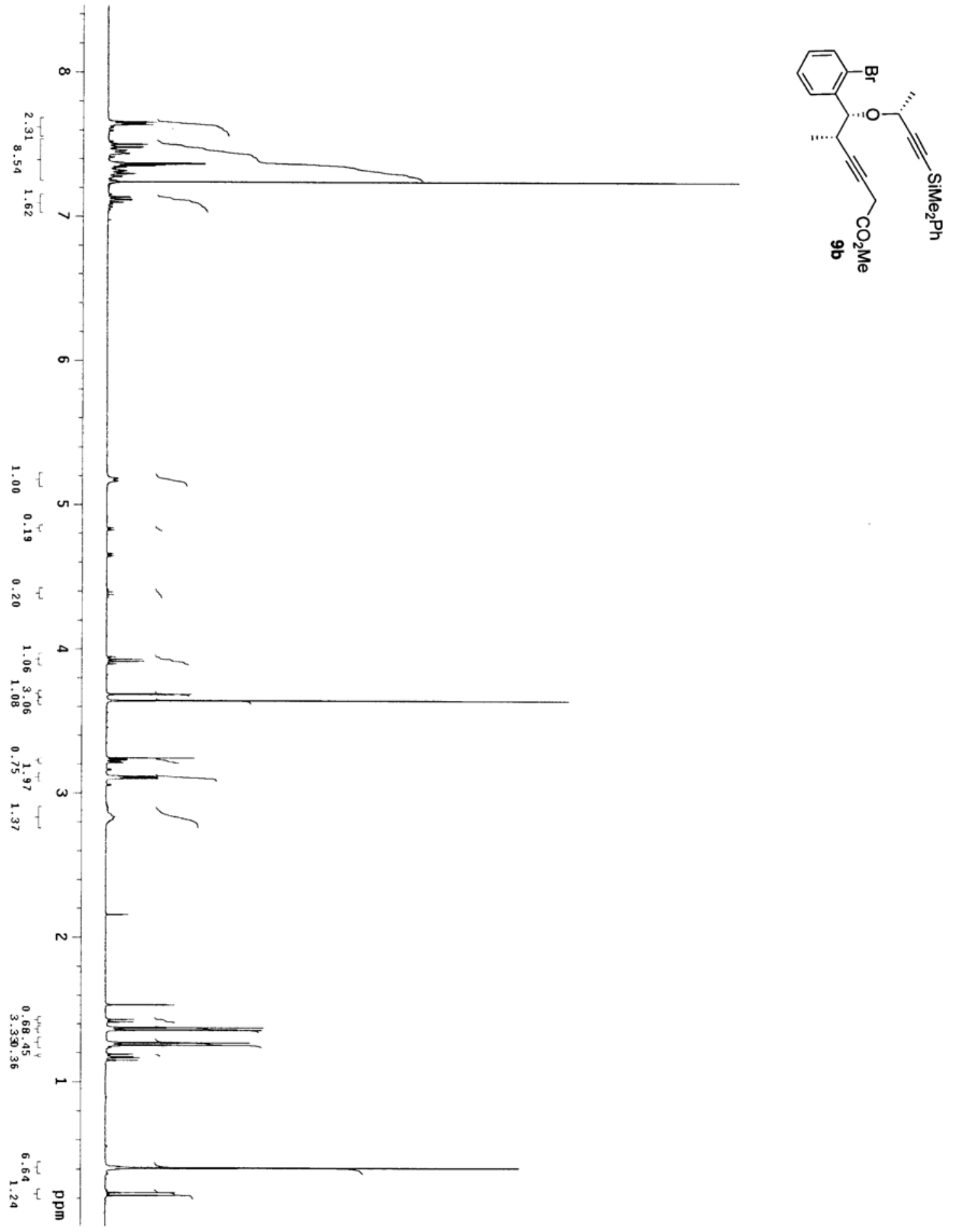




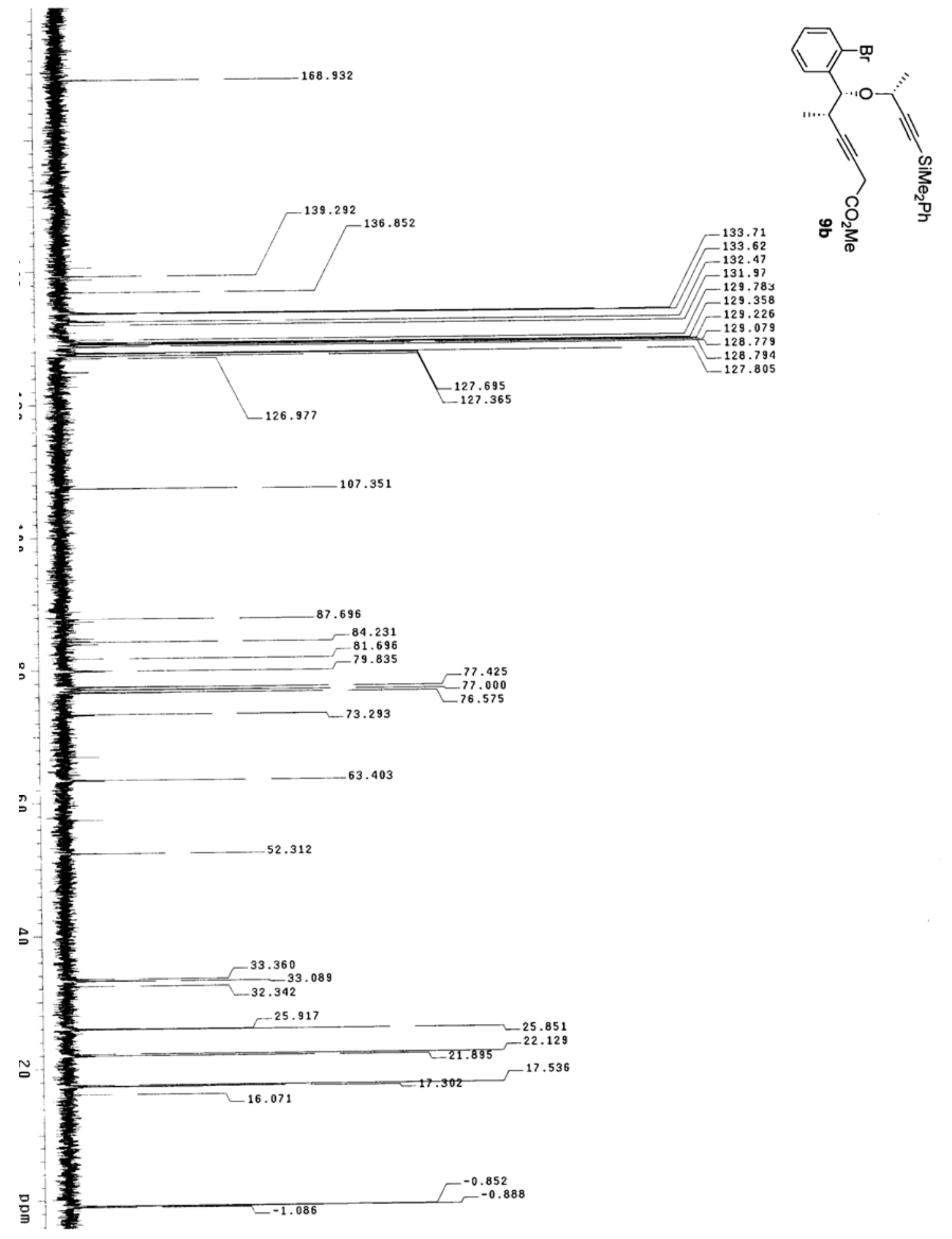




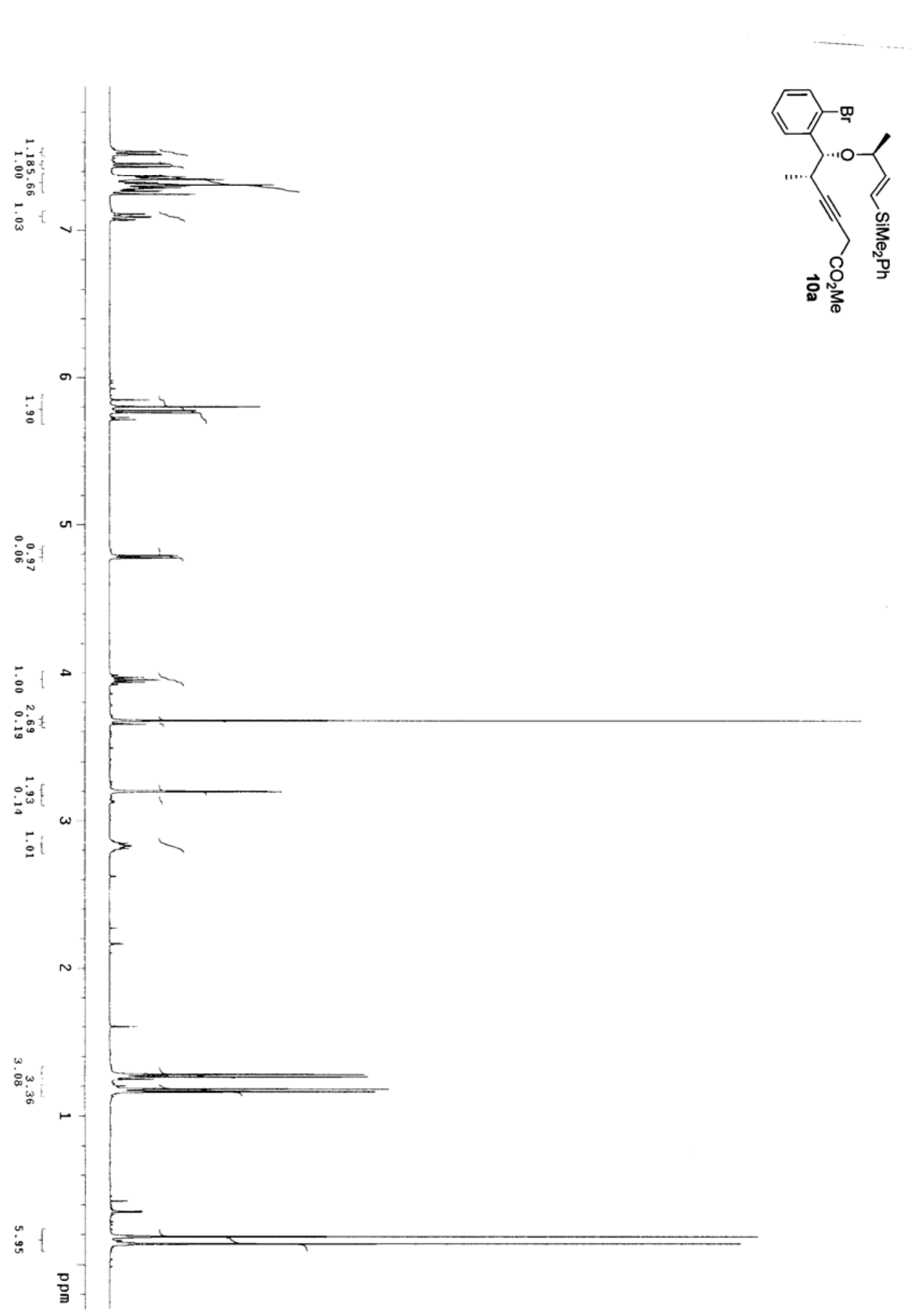




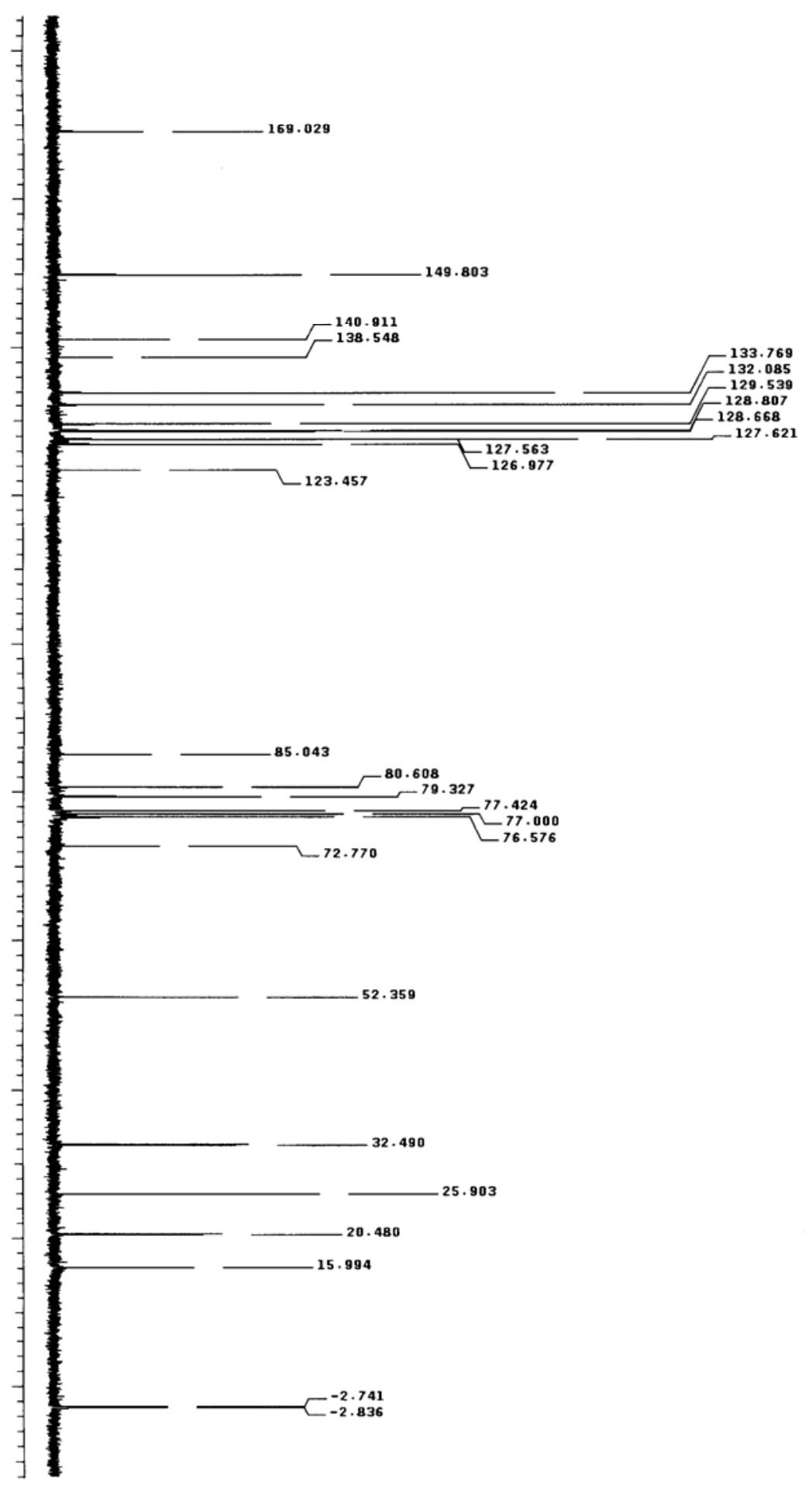




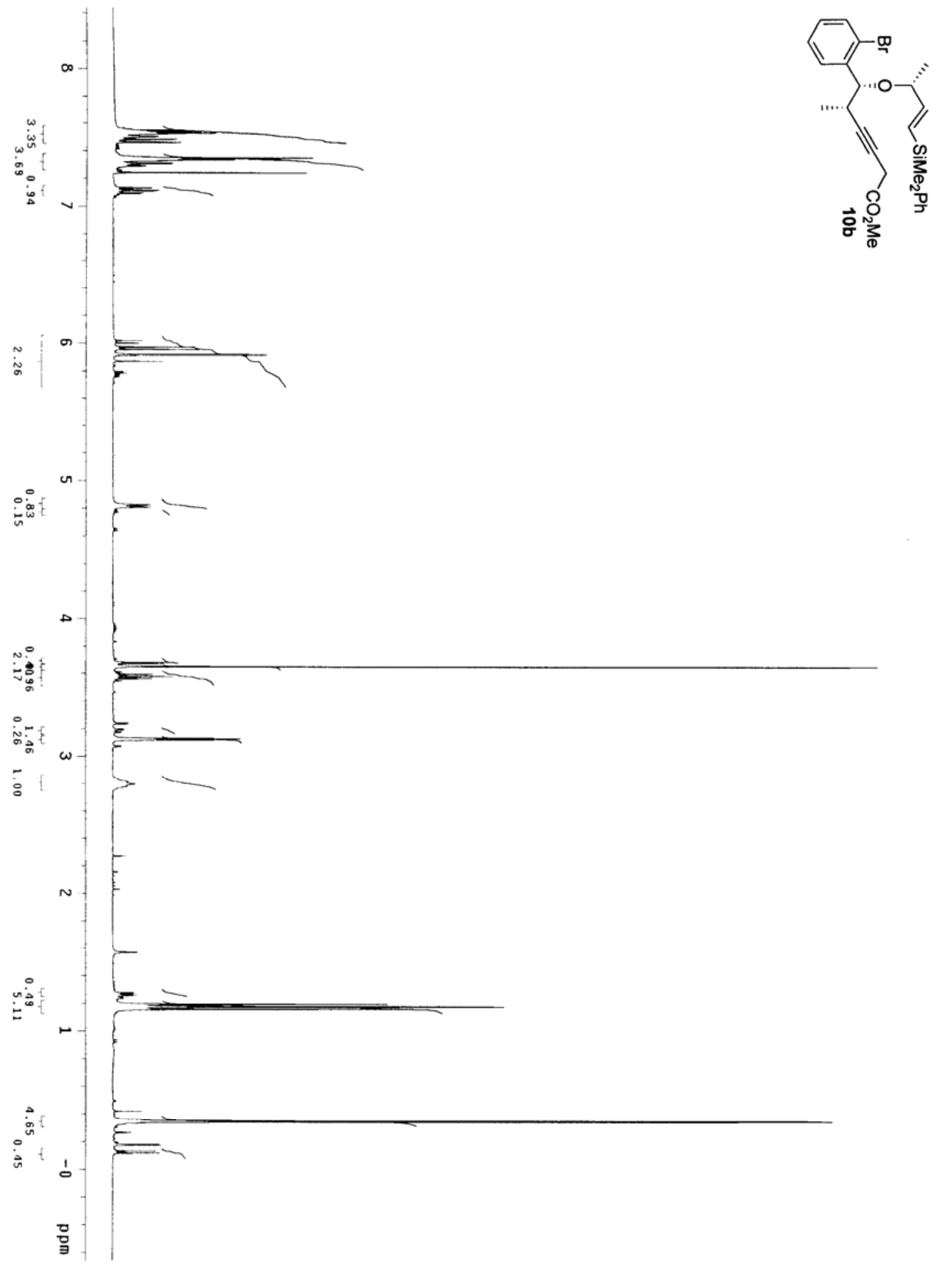




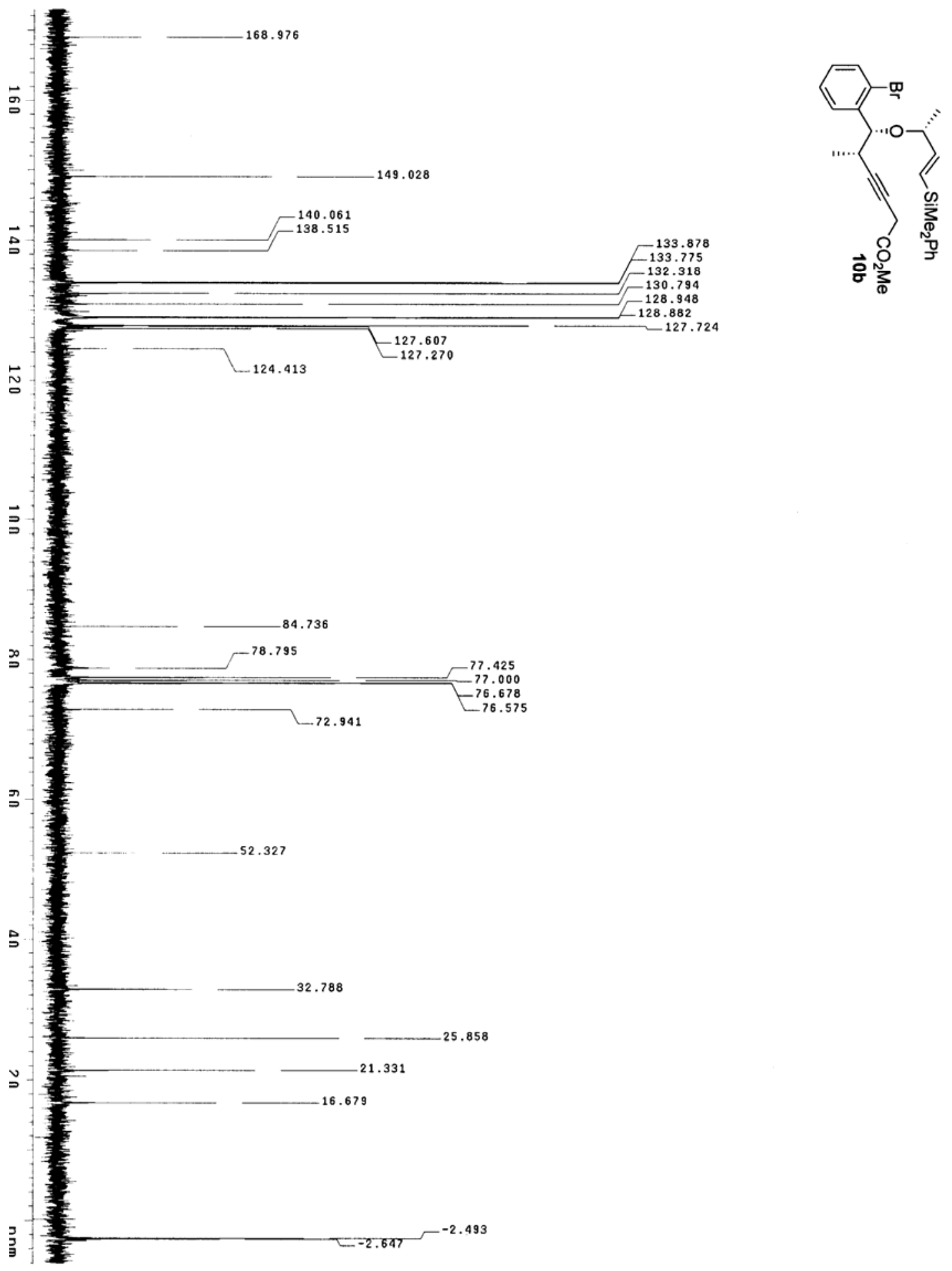

